NBER WORKING PAPER SERIES

LEADERSHIP AND COOPERATION IN THE EUROPEAN
MONETARY SYSTEM: A SIMULATION APPROACH

Nouriel Roubini

Working Paper No. 3044

NATIONAL BUREAU OF ECONOMIC RESEARCH

1050 Massachusetts Avenue

Cambridge, MA 02138

July 1989

I would like to thank Jeff Sachs, Warwick Mckibbin and Susan Collins for many discussions and helpful comments. Valuable comments and suggestions were made on an earlier draft in seminars at Carnegie-Mellon University, Harvard

University, Johns Hopkins University, the International Monetary Fund, New York University, UC Berkeley, UC San Diego, University of Michigan Ann Arbor and Yale University. Of course, all remaining errors are mine. This paper is part of NBER's research program in International Studies. Any opinions expressed are those of the author not those of the National Bureau of Economic Research. 
NBER Working Paper \#3044

July 1989

\title{
LEADERSHIP AND COOPERATION IN THE EUROPEAN MONETARY SYSTEM: A SIMULATION APPROACH
}

\begin{abstract}
To assess the importance of economic interdependence and the potential gains from policy coordination in the European area, this paper analyzes the international transmission of policies and disturbances in a rational expectation dynamic general equilibrium simulation model of the work economy, and applies the analysis to the study of the European Monetary System. International spillover effects and potential gains from coordination appear to be small under the assumption of flexible exchange rates in the European area. The implications of a fixed rate EMS with German leadership are compared with those of a cooperative fixed exchange rate regime. Finally, capital controls under fixed rates fails to insure policy autonomy and insulation from external disturbances for the couritries restricting the capital movements.
\end{abstract}

Nouriel Roubini

Economics Department

Yale University

P.O. Box 1972 Yale Station

New Haven, CT 06520 


\section{Introduction.}

In the last few years we have observed a large and growing interest in the question of the international coordination of economic policies. From a theoretical point of view the question is clear: cooperative equilibriun solutions are Pareto superior to noncooperative Nash equilibria and therefore policy coordination must be welfare improving 1 . However, when one goes to measure empirically the welfare gains from cooperation ${ }^{2}$, one finds that the potential gains from policy coordination appear to be very small.

This surprising result can be understood by observing that the gains from policy coordination depend on the size of the externalities deriving from the spillover effects of policies across countries. The size of these extemalities depend in turn on the degree of interdependence among the different countries. The greater (lower) the degree of interdependence the greater (smaller) the potential gains from policy coordination. Interdependence depends in turn on a number of factors: the size of the trade and financial linkages between countries (i.e. the degree of econonic integration); the relative size of different countries; and the exchange rate regime.

The relevance of the third factor depends on the idea that the international transmission of economic disturbances and policies may be very different under altemative exchange rate regines. In particular, a number of open macro models suggest that transmission effects might be small under flexible exchange rates given the greater insulation properties of this regime. This observation leads to suspect that the small gains from policy coordination in the OECD area found in previous research may depend on

1. Exceptions are the cases of counterproductive cooperation as in Rogoff (1985).

2. See Oudiz and Sachs (1984), Ishii, McKibbin and Sachs (1985), Sachs and McKibbin (1986) and Sachs and Roubini (1987) for results based on simulation models. The absence of large gains from coordination is also implicit in the small international multipliers found in most large macroeconometric models of the world economy. On these multipliers, see the results of the summary volume [Bryant, Henderson, Holtham, Hooper, Symansky (1988)]) of the Brookings project comparing 12 macro-models of the world economy. 
the relatively small trade linkages between the U.S., Japan and the Rest of the OECD and on the existence flexible exchange rates among these regions. One is also led to suspect that the degree of interdependence (and the potential gains from policy coordination) may be much larger among the countries forming the European Monetary System: this region is, in fact, characterized by a very high degree of opemess and economic integration between the member countries and by a system of substantially fixed exchange rates.

To assess empirically the importance of economic interdependence and the potential gains from policy coordination under different exchange rate regimes, this paper will analyze the international transmission of monetary and fiscal policy under alternative exchange rate regimes by using an enlarged version of the MSG model, a rational expectation dynamic general equilibrium simulation model of the world economy, and will apply the analysis to the case of the European Monetary System (EMS).

Modelling a system of fixed exchange parities requires the specification of the rules of the regime, i.e. how the burden of maintaining the fixed parity is shared by the countries joining a fixed rate system. In modelling the EMS in this paper, I will formulate and compare altemative assumptions about the EMS rules of the game. This will allow us to discuss a number of important questions. Is the degree of interdependence among the EMS countries very large so that the potential gains from policy coordination in the EMS area are significant ? Is it correct, as claimed by some authors, that the EMS is an exchange rate union where Germany exerts a leadership or hegemonic role while the monetary policy of the other members is determined passively once the German policy is set ${ }^{3}$ ? Or are there mechanisms that make the burden of adjustment in the EMS more symetric and the resulting setting of monetary policy more cooperative ?

3. For example, Giavazzi and Giovannini (1987, 1989) define the EMS as a "greater Deutsche-Mark" area. 
Another set of questions regards to the role of imperfect capital mobility and substitutability in sustaining a fixed rate regime: it has been often argued (see Giavazzi and Pagano (1986), Giavazzi and Giovannini (1986, 1989)) that the EMS has been a viable exchange regime because capital controls in countries like France and Italy have limited the potentially disruptive effects on the EMS of disturbances extemal to the system (like movements of the dollar) or various asymmetries between the EMS countries. Do capital controls allow countries in the EMS to regain part of the monetary autonomy lost by joining the EMS ? How do capital controls affect the effectiveness of domestic policies and their international trarsmission in the EMS area?

As a starting point of the analysis, in Section 2, a new 9-country version of the MSG model is used to perform policy simulations under the hypothetical assumption of flexible exchange rates and perfect capital mobility in all the countries, including the EMS ones. Following this case, in Section 3 a fixed exchange rate regime is modelled for the EMS countries by assuning that Germany is the leader of the EMS and that perfect capital mobility holds in all regions. The Geman leadership hypothesis might be extreme given that the EMS agreements provide rules for a more symmetric burden of adjustment among the participating countries. In Section 4, I therefore model a cooperative EMS system where a cooperative rule is used to determine the intervention of each country in the exchange market so as to maintain a fixed rate between the union currencies. The crucial role of sterilization policies of the foreign reserve flows resulting from the interventions in the exchange rate markets is then discussed. Next, in Section 5, imperfect capital mobility is introduced by assuming wide capital controls in France and Italy so that the capital account of the balance of payments is zero in these countries. The implications of limited capital mobility for the EMS are then discussed. Section 6 contains some concluding remarks.

\section{The Kodel.}


The model used in this paper is an enlarged version of the MSG model that is a dynamic general equilibrim model of the world economy. Previous versions of the model (Ishii, McKibbin and Sachs(1985), Sachs and McKibbin (1986), McKibbin (1986), McKibbin, Roubini and Sachs (1987), Sachs and Roubini (1987)) differ from the one being presented here in a number of aspects. One major difference is that earlier versions of the model analyzed policy interactions in the OECD region under the hypothesis of flexible exchange rates. This assumption is reasonable in analyzing the interaction between the US, Japan and the Rest of the OECD countries. Here, however, the focus of the analysis is turned to a comparison of alternative exchange rate regimes and a to a study of the major current example of a substantially fixed exchange rate regine (the EMS).

Second, in previous versions the OECD bloc was disaggregated in only 3 regions (U.S., Japan and the Rest of the OECD). Given the focus of the present paper on the EMS, it is necessary to disaggregate the Rest of the OECD bloc in a number of sub-regions. The modelling strategy followed here is to keep U.S and Japan and disaggregate the Rest of the OECD in five areas: Germany, France, Italy, the Rest of the EMS (comprising Belgium, Denmark, Ireland, Luxembourg and the Netherlands) and a residual Rest of OECD bloc (UK, Canada and the other OECD countries). As a result, this version of the model includes 9 regions: The seven OECD regions above plus OPEC and the LDC bloc.

The model is of moderate size (about three dozen behavioral equations per industrial region). It is distinctive relative to most other global models in that it solves for a full intertemporal equilibrium in which agents have rational expectations of future variables. In theoretical conception, therefore, the model is close in design to intertemporal dynamic models of fiscal policy in Lipton and Sachs (1983) and Frenkel and Razin (1986). Those studies, like the present simulation model give considerable attention to intertemporal optimization and intertemporal budget constraints. The model has a mix of Keynesian and classical properties by virtue of a maintained assumption of 
slow adjustment of nominal wages in the labor markets of the U.S., Europe and the ROECD (Japan is treated differently, as described below).

The model is solved in a linearized form, to facilitate policy optimization exercises with the model, and especially to use linear-quadratic dynamic game theory and dynamic programing solution techniques. The global stability of the linearized model can be readily confirmed by an analysis of the model's eigenvalues. ${ }^{4}$ At this point, the model is parametrized by choosing parameters based on existing econometric research in the literature, rather than by undertaking our own econometric estimation of the model parameters. However, the robustness of the simulation results is repeatedly tested through a systematic sensitivity analysis of the parameters of the model.

The model has several attractive features. First, all stock-flow relationships are carefully observed. Budget deficits, current accounts and physical investment flows cumulate into their respective stocks. Underlying growth of Harrod-neutral productivity plus labor force growth is assumed to be 48 per region. Given the long-run properties of the model, the world econony settles down to the 48 steady-state growth path following any set of initial disturbances.

A second feature is that the asset markets are efficient in the sense that asset prices are detemined by a combination of intertemporal arbitrage conditions and rational expectations. By virtue of the rational expectations assumption and the forward-looking behavior of households and firms, the model can be used to examine the effects of anticipated future policy changes. Indeed each simulation requires that the "entire" future path of anticipated policies be specified.

4. In general, quantity variables are linearized around their levels relative to potential GDP, while price variables are linearized in $\log$ form. The flexible rate version of the model contains 20 jumping (forward looking) variables, 65 state variables and over 300 endogenous variables. The saddle path manifold for the jumping variables is obtained through a dynamic programing algorithm described in Oudiz and Sachs (1985). The model is parametrized using actual 1986 trade shares and asset stocks. 
A third feature of the model is the specification of the supply side. There are several noteworthy points here. First, factor input decisions are based on intertemporal profit maximization by firms. Labor and intenmediate inputs are selected to maximize short-run profits given a stock of capital which is fixed within each period. The capital stock is adjusted according to a "Tobin's q" model of investment. Tobin's $\mathrm{q}$ is the shadow value of capital, and evolves according to a rational expectations forecast of future post-tax profitability. Another point regarding the supply side is the specification of the wage-price dynamics in each of the OECD regicns. Extensive macro research has shown important differences in the wage-price processes in the U.S., Europe, and Japan, and these differences are incorporated in the model.

We will now describe in more detail the structure of the model considering the flexible exchange rate - perfect capital mobility version of it. Only the equations for the U.S. will be described in detail while those for the other regions will be discussed only when different from the U.S, equations. Each of the regions in the model produces a good which is an imperfect substitute in the production and spending decisions of the other regions. Each industrialized region produces one final good which is used for investment and consurption purposes in that region and in all of the other regions. IDC and OPEC each produce one good which is a primary input in the production processes of the industrial regions. Demands for the outputs of LDC and OPEC are therefore derived demands for the production imputs. Only the seven industrial country regions are fully modelled with an intemal macroeconomic structure. In IDC and OPEC, only the foreign trade and external financial aspects are modelled. Note that in referring to variables of the various regions, we will use the following notation: U.S. (U); ROECD (R); Japan (J); Germany (G); France (F); Italy (I); REMS (C); OPEC (O); and IDC (L).

\section{Firms}


The cornerstone of aggregate supply in the model is a representative firm which maximizes income by producing a single output $Q$ at price $P$, subject to a three-input production function (for simplicity, potential growth is ignored in the equations that follow, even though a constant underlying potential growth rate of 4 percent is included in the model). Thus, aggregate gross output equation is given as a Cobb-Douglas function of labor (L), capital (K) and primary imported inputs (N) :

$\mathrm{Q}^{\mathrm{U}}=\beta_{19}\left(\mathrm{~L}^{\mathrm{U}}\right)^{\beta_{8}}\left(\mathrm{~K}^{\mathrm{U}}\right)^{\beta_{9}}\left(\mathrm{~N}^{\mathrm{U}}\right)^{\beta} 10$

Gross output $Q$ is a produced with value added V (produced with capital and labor), and primary inputs $N$. $N$, in turn, is produced with the imports from OPEC (net of domestic oil production) $\mathrm{N}_{\mathrm{O}}$ and the LDCs $\mathrm{N}_{\mathrm{L}}$ according to a CES function :

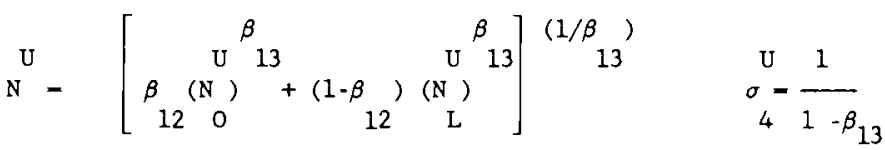

The capital stock $\mathrm{K}$ changes according to the rate of fixed capital formation $\mathrm{J}$ and the rate of geometric depreciation $\delta$ :

$\mathrm{K}_{\mathrm{t}+1}=\mathrm{J}_{\mathrm{t}}+(1-\delta) \mathrm{K}_{\mathrm{t}}$

$J$ is itself a composite good, produced with a Cobb-Douglas technology that has as inputs the domestic good and the final goods of the other 6 OECD regions 5 :

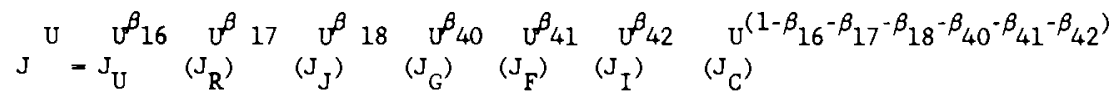

Imports demand for investment goods from each region are then easily derived from the $J$ function above. As is customary in modern models of investment, it is assumed that the investment process is subject to rising marginal costs of installation, with total nominal investment expenditures $P^{J} I$ equal to the value of direct purchases of investment $P^{J} \star J$, plus the per unit costs of installation. These per unit costs, in

5. The price of $J$ is simply a weighted sum of the prices of the home goods and the dollar import prices of goods from the other OECD regions. 
turn, are assumed to be a linear function of the rate of investment $\mathrm{J} / \mathrm{K}$, so that adjustment costs are $\mathrm{P}_{\star \mathrm{J}}^{\mathrm{J}}\left[\left(\beta_{15} / 2\right)(\mathrm{J} / \mathrm{K})\right]$. Total irvestment expenditure is therefore:

$\mathrm{P}^{\mathrm{JU}} \mathrm{I}^{\mathrm{U}}=\mathrm{P}^{\mathrm{JU}} \quad \mathrm{J}^{\mathrm{U}}\left[1+\left(\beta_{15} / 2\right) \mathrm{J}^{\mathrm{U}} / \mathrm{K}^{\mathrm{U}}\right]$

The goal of the firm is to choose imputs of $\mathrm{L}, \mathrm{N}$, and $\mathrm{J}$ to maximize intertemporal net-of-tax profits. The fim's problem, formally stated, is:

$\max \sum_{\tau=t}^{\infty}\left(1+R_{\tau}\right)^{-1}\left[\mathrm{Q}-(\mathrm{W} / \mathrm{P}) \mathrm{L}-\left(\mathrm{P}_{\mathrm{N}} / \mathrm{P}\right) \mathrm{N}-\left(\mathrm{P}^{\mathrm{J}} / \mathrm{P}\right) \mathrm{I}\right]$

where $\left(1+R_{T}\right)^{-1}$ is a discount factor equal to $\prod_{i=t}^{r}\left(1+r_{i}\right)^{-1}$ and $r_{i}$ is the

period $i$ short-term real interest rate. The solution to this problem has three key points. First, inputs of $\mathrm{L}$ and $\mathrm{N}$ are hired to the point where marginal prodictivities of these factors equal their factor prices. This leads to equations for the derived demand for $\mathrm{L}$ and $\mathrm{N}$ of the form :

$\mathrm{L}^{\mathrm{U}}=\beta_{8}\left[\mathrm{P}^{\mathrm{U}} \mathrm{Q}^{\mathrm{U}} / \mathrm{W}^{\mathrm{U}}\right] \quad \mathrm{N}^{\mathrm{U}}=\beta_{10}\left[\mathrm{P}^{\mathrm{U}} \mathrm{Q}^{\mathrm{U}} / \mathrm{P}^{\mathrm{nU}}\right]$

$\mathrm{N}_{\mathrm{O}}=\left(\beta_{12}\left[\mathrm{P}^{\mathrm{nU}} \mathrm{N}^{\mathrm{U}} / \mathrm{P}^{\mathrm{O}}\right)\right\}^{\sigma / 4}-\mathrm{OIL}^{\mathrm{U}} \quad \mathrm{N}_{\mathrm{L}}=\left(\left(1-\beta_{12}\right)\left[\mathrm{P}^{\mathrm{nU}} \mathrm{N}^{\mathrm{U}} / \mathrm{P}^{\mathrm{L}}\right]\right)^{\sigma}$

Gross fixed capital formation can be written in terms of Tobin's "marginal" $q$, as;

$\mathrm{J}^{\mathrm{U}}=\beta_{29}\left[\left(\mathrm{q}^{\mathrm{U}}-1\right) / \beta_{15}\right] \mathrm{K}^{\mathrm{U}}$

Third, the equation of motion of $q$ (the shadow value of investment) is given by:

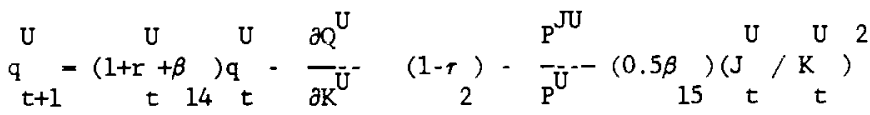

where the marginal product of capital is:

$\frac{\partial \mathrm{Q}^{\mathrm{U}}}{\partial \mathrm{K}}={ }_{9}^{\mathrm{U}}\left(\mathrm{Q}^{\mathrm{U}} / \mathrm{K}^{\mathrm{U}}\right)$

Then, $q$ equals the discounted value of future profits, with $q$ given by:

$\mathrm{q} /\left(\mathrm{P}^{\mathrm{J}} / \mathrm{P}\right)=\sum_{\tau=\mathrm{t}}^{\infty}\left(1+\mathrm{R}_{\tau}\right)^{-1}\left(\mathrm{~F}_{\mathrm{K}}+\Phi_{\mathrm{K}}\right)$

Here $F_{k}$ is the marginal product of capital in the production function, and $\Phi_{K}$ is the marginal product of capital in reducing adjustment costs in investment. 
In the specific application in the model, the gross output production function is taken to be a two-level CES function in $\mathrm{V}$ and $\mathrm{N}$, with $\mathrm{V}$ a Cobb-Douglas function of $\mathrm{L}$ and $K$, and $N$ a CES function of oil and non-oil primary inputs. The investment function derived in (11) is also modified, for empirical realism, by writing $J$ as a function not only of $q$, but also of the level of flow capital income at time $t$, and the change in the level of gross output, along standard imvestment accelerator lines. The modified investment equation is of the form:

$\mathrm{J}^{\mathrm{U}}=\beta_{29}\left(\mathrm{q}^{\mathrm{U}}-1\right)\left(1 / \beta_{15}\right) \mathrm{K}^{\mathrm{U}}+\left(1-\beta_{29}\right)\left(\mathrm{Q}^{\mathrm{U}}-\mathrm{W}^{\mathrm{U}} \mathrm{L}^{\mathrm{U}} / \mathrm{P}^{\mathrm{U}}-\mathrm{P}^{\mathrm{nU}} \mathrm{N}^{\mathrm{U}} / \mathrm{P}^{\mathrm{U}}\right)+\beta_{32}\left(\mathrm{Q}_{\mathrm{t}}-\mathrm{Q}_{\mathrm{t}-1}\right)$

The supply side of the U.S. block of the model is completed with the wage equation, which makes the nominal wage change a function of past consumer price ( $p^{c}$ ) changes, rationally expected future price changes, and the level of unemployment in the econoxy, according to an augmented Phillips curve mechanism:

${ }_{t+1}^{U}-w_{t}^{U}+\beta \underset{25}{\left(p_{t+1}^{c U}-p_{t}^{c U}\right)+(1-\beta)\left(p^{c U}-p_{t-1}^{c U}\right)+0.1\left(L^{U}-L^{f}\right)}$

where $\mathrm{w}-\log \mathrm{W} ; \mathrm{P}^{c}=\log \mathrm{P}^{c} ;$ and where $L^{f}$ represents the inelastically supplied full-employment stock of labor. The parameter $\beta_{25}$ determines how much weight is given to backward-looking versus forward-looking price expectations. Given the wide evidence on the greater degree of real wage stickiness in Europe compared with the US, $\beta_{25}$ is chosen to be larger for the European countries. We also allow for differences in the wage dynamics of the different regions. In Japan, we specify that wages are set one period ahead at their expected market clearing levels. Thus, let $\left(t_{t} w_{t+1}\right)$ be the wage expected to clear the labor market at time $t+l$. Then:

\section{households}

$$
w_{t+1}^{J}=\left(t_{t+1}^{J}\right)^{f}
$$

Consider next the demand side of the model. Total private consumption spending $P * C$ is written as a function of labor income net of labor taxes ( $\tau_{L}$ is the labor income tax rate), and total nominal financial wealth $P * F$, as in: 


$$
\mathrm{P}^{\mathrm{cU}} \mathrm{C}^{\mathrm{U}}-\beta_{28} \mathrm{P}^{\mathrm{U}} \mathrm{F}^{\mathrm{U}}+\beta_{31}\left[\mathrm{~W}^{\mathrm{U}} \mathrm{L}^{\mathrm{U}}\left(1-\tau_{1}\right)-\mathrm{TAX}^{\mathrm{U}}+\mathrm{P}^{\mathrm{O}} \text { OIL } \mathrm{U}^{\mathrm{U}}\right]
$$

This equation is certainly the most problematic of the model. The equation is an ad-hoc compromise between alternative conceptions of aggregate consumption, in line with the empirical evidence that consumption is partiy determined along life-cycle lines, with considerable intertemporal consumption smoothing, and partly along simpler Keynesian lines (because of liquidity constrained households). Thus, we specify that spending is a fixed proportion of current net-of-tax labor income (with no consumption smoothing of the labor income flow), as in standard Keynesian models, and a fixed proportion of wealth, as in standard life-cycle models with infinite-lived individuals.

Once $P^{c} \star C$ is determined, it is divided into purchases of the domestic good $(C d$ ), and imported final goods $\left(C^{\mathrm{mU}}\right)$. The division of $P^{c} \star C$ is made to maximize an instantaneous utility function of CES form:

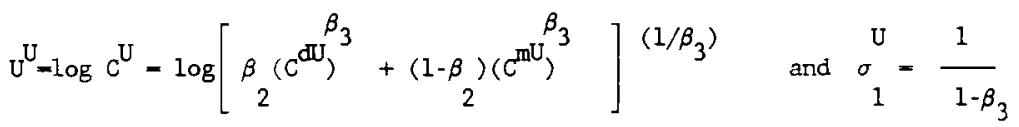

Consumption of imports is in turn a CES function of the imports of goods from the ROECD $\left(C_{R}^{U}\right)$, Japan $\left(C_{J}^{U}\right)$, Germany $\left(C_{G}^{U}\right)$, France $\left(C_{F}^{U}\right)$, Italy $\left(C_{I}^{U}\right)$ and the rest of the EMS $\left(C_{C}^{U}\right)$ :

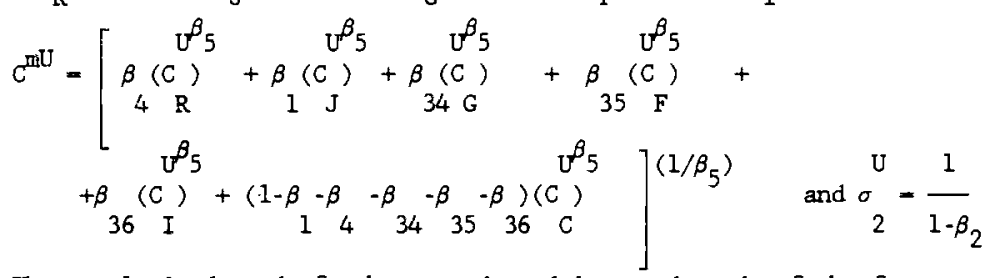

The result is demands for home goods and imported goods of the form:

$C^{\mathrm{dU}}=C^{\mathrm{U}}\left(\mathrm{P}^{\mathrm{cU}} / \mathrm{P}^{\mathrm{U}}\right)\left(1 / 1+\Omega_{1} \beta_{6}\right)$
$C^{\mathrm{mU}}=C^{\mathrm{U}}\left(\mathrm{P}^{\mathrm{cU}} / \mathrm{P}^{\mathrm{mU}}\right)\left[\Omega_{1} \beta_{6} /\left(1+\Omega_{1} \beta_{6}\right)\right]$

where $\left.\left.\beta_{6}=\left(\left(1-\beta_{2}\right) / \beta_{2}\right){ }^{\sigma} \quad \Omega_{1}=(P / P)^{\mathrm{mU}}\right)^{\left(1-\sigma^{U}\right.}\right)$

and U.S imports from country $j\left(C^{U}{ }_{j}\right)$ are: 


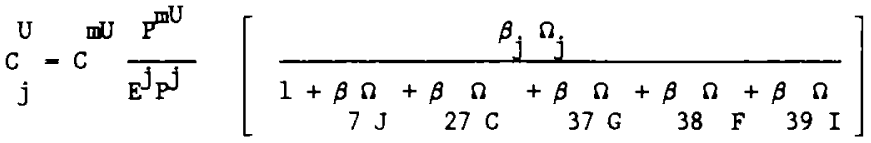

where: $\left.\Omega_{1}-\left(E^{i} P^{i} / E^{R} P\right)^{\left(1-\sigma^{U}\right.}{ }^{2}\right)$ for $j-R, J, G, C, F, I 6$

\section{Asset Markets, Balance of Payments and the Government Sector}

The rest of the model can be quickly stated. Prices in the U.S. (and the other OECD regions) are fully flexible within each period, so that demand for U.S. output (domestic demand plus export demand) equals output supply. Money demand equations are specified for each OECD region in a standard transactions demand equation:

$\left(\mathrm{M}^{\mathrm{U}} / \mathrm{P}^{\mathrm{U}}\right)-\sigma_{6} \mathrm{Q}^{\mathrm{U}}-\sigma_{7} \mathrm{i}^{\mathrm{U}}$

Asset markets are assumed to be perfectly integrated across the OECD regions. Expected returns of loans denominated in the currencies of the various regions are equalized period to period, according to the following interest arbitrage relations:

$$
i_{t}^{i}-i_{t}^{j}+t^{\left(e^{i}{ }_{j} t+1\right.}-e^{i} j t
$$

Thus, we do not allow for risk premia on the assets of altemative currencies. We choose the assumption of perfect capital mobility and zero risk premia in light of the failure of the empirical exchange rate literature to demonstrate the existence of stable risk premia across intemational currencies.

For the seven OECD regions and OPEC, the current account is determined under the assumption that domestic agents have free unrationed access to international borrowing and lending at the international interest rate. It is assumed for simplicity that all intemational borrowing and lending takes place in dollar denominated assets. The real exchange rates of the U.S. Dollar $\left(\wedge^{\prime} s\right)$ are defined as:

$\wedge^{j}-P^{j} E^{j} / P^{U} \quad j=R, G, F, I, C ; \wedge^{L}-P^{L} / P^{U} \quad \wedge^{O}=P^{O} / P^{U}$ 6. We also assume that the government divides spending $G$ among the final goods in the
same proportion as does the private sector, so that: $\mathrm{G}^{\mathrm{I}} / \mathrm{G}^{\mathrm{f}}-\mathrm{C}^{1} / \mathrm{C}^{\mathrm{f}}$. 
Real GNP is defined as gross output minus primary goods irquts plus domestic oil income and interest payments on net foreign assets while real gross output is:

$Q^{U}=P^{C U}\left(C^{U}+G^{U}\right) / P^{U}+I^{U} / P^{U}+T B^{U}+\left(P^{n U} N^{U}-P^{O}\right.$ OIL $\left.L^{U}\right) / P^{U}$

Real financial wealth is the sum of public debt (B), net foreign assets (the $A_{j}^{i}{ }^{\prime} s$ ), value of equity $(q K)$ and real money balances $(M / P)$ :

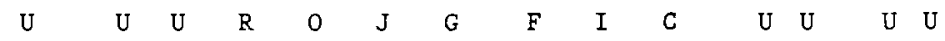

$F=B+A_{L}-A_{U}-A_{U}-A_{U}-A_{U}-A_{U}-A_{U}-A_{U}+q K+(M / P)$

The expectations hypothesis on the relation between short and long term interest rates is described by:

$r_{t}^{U}=R_{t}^{U} \cdot\left(R_{t}^{U}{ }_{t+1}^{-R^{U}}{ }_{t}\right) / R_{t}^{U}$

and the nominal interest rate is equal to the sum of the real interest rate and the inflation rate:

${ }_{i}^{U}{ }_{t}=r_{t}^{U}+\Pi_{t}^{U}$ where: $\Pi_{t}^{U}=\left(P_{t+1}^{U}-P_{t}^{U}{ }_{t} / P_{t}^{U} I_{t}^{c U}=\left(P_{t+1}^{c U}-P_{t}^{c U}\right)^{c / P U}\right.$

A final set of equations for the U.S. represents the behavior of the government sector. The public sector deficit (or public debt accumulation) is equal to government expenditures plus interest payment on the public debt mimus taxes:

${ }_{B}^{U}{ }_{t+1}-B_{t}^{U}(1-\alpha)-D E F^{U}=G^{U}+r B_{t}^{U}-T^{U}$

Taxes are the sum of an autonomous component, labor income and corporate taxes:

$\mathrm{T}^{\mathrm{U}}=\mathrm{TAX}+\left[\tau_{1} \mathrm{~W}_{\mathrm{L}}^{\mathrm{U}}+\tau_{2}\left(\mathrm{Q}^{\mathrm{U}}-\mathrm{W}_{\mathrm{L}}^{\mathrm{U}}-\mathrm{P}^{\mathrm{nU}}{ }_{\mathrm{N}}^{\mathrm{U}}\right)\right] / \mathrm{P}^{\mathrm{U}}$

and autonomous taxes (TAX) are equal to interest on debt ( $r B$ ) and an exogenous lump-sum component (TAXE). Finally, the model is closed with the foreign asset accumulation and trade equations for the OPEC and LDC bloc that can be found in Roubini (1988a).

\section{Flexible exchange rates and perfect capital mobility.}

In this section the model is solved for the case of a global flexible exchange rate regime and perfect capital mobility in each region. We will consider a number of policy shocks starting with monetary policy. The results for a monetary expansion in the U.S. under flexible rates and perfect capital mobility replicate those obtained by Sachs and 
Roubini (1987) and Mckibbin, Roubini and Sachs (1987). As Table 1 shows, a permanent increase in the U.S. money supply of 1 percent causes the output to rise by 0.78 in the first year and causes the nominal exchange rate of the dollar to depreciate by about 1.2-1.3 while the real exchange rate depreciates by $1.00-1.07$ percent on impact. Inflation goes up, the initial real depreciation is reduced over time by the increase in domestic prices and output falls through time back to its steady state value. The transmission effects of monetary policy are minimal: there is almost no effect of the U.S. expansion and dollar depreciation on the U.S. trade balance, or on output or the trade balance in other regions; the spillover effects of monetary policy to other regions are practically zero.

One could suspect that these results depend on the small degree of economic interdependence between the U.S., Japan and the ROECD and that the transmission of monetary policy would be greater in a region of greater economic integration like Europe. The results for monetary expansions in Germany, France, Italy and the REMS fail to confirm the hypothesis. As can be seen from Table 2, that shows the results of a monetary expansion in Germany, the effects of monetary policy are again only domestic and the transmission of these policies to the other EMS and non-EMS countries is close to zero. The same small spillover effects are obtained for monetary expansions originating in France, Italy and the REMS ${ }^{7}$.

The main and strong result for all the monetary policy simulations is the lack of transmission of domestic monetary policies to other regions under flexible exchange rates. This result, already found for the transmission of U.S. and Japanese monetary policies, is found to hold also for an area of greater economic integration like Europe. The result is consistent with the theoretical ambiguity of the sign of the transmission of monetary policy in a general Mundell-Fleming model.

7. These results are available upon request from the author. 
We move next to the effects of fiscal policy. Table 3 present the results for a fiscal expansion in the U.S. consisting in a permanent $1 \%$ of GNP increase in real government expenditures which is financed by goverment debt. Initially, output rises above its steady state value (by $0.33 \&$ in the first year). The nominal and real exchange rates appreciate ( by more than 48 ) and the trade balance worsens by 0.25 of GNP. Over time the stimulative effect of fiscal policy is dampened by rising interest rates, a worsening trade balance and the increased taxes raised to finance the increased public debt; consurption and investment are crowded out and the real output multiplier falls back to zero. The transmission of this fiscal shock to the rest of the world is larger than the transmission of monetary policy. As predicted by the Mundell-Fleming model, the transmission is initially positive as the trade balances of the other regions improve following the dollar appreciation and the increased aggregate demand in the U.S. but, starting in the second year, the negative effects of rising interest rates lead to an output fall in the rest of the world.

The effects of fiscal policy expansions in the other regions of the world are qualitatively similar to the U.S. Ones (see Table 4 for the case of a German fiscal expansion). The main differences are in the magnitude of the effects. For example, a 1 o fiscal expansion in a country smaller than the U.S. leads to an asset price effects that smaller than those deriving by a U.S. fiscal expansion: the pressure on world savings deriving from a fiscal expansion in a small country is lower and therefore the effects on world interest rates and exchange rates lower. As a consequence, the crowding out of investment and the shift in demand from comestic to foreign goods are also smaller; therefore, also the international transmission effects are smaller. We observed above that the high degree of economic integration in Europe did not lead to any significative inter-European transmission of monetary policy. The results for fiscal policy confirm this result of a modest transmission for fiscal policy as well. For example, a 18 of GNP 
German fiscal expansion leads to an increase in output in the other EMS countries of the order of $0.04-0.06 \%$ of GNP of the other European countries in the first year. Conversely, the negative transmission of German fiscal policy after the first period is modest as well. Transmission is even smaller when one of the smaller European countries is the source of the fiscal expansion ${ }^{8}$.

The main result of this section is that under flexible rates and perfect capital mobility the international spillover effects of both monetary and fiscal policy from one European country to the other would be very small ${ }^{9}$. These results suggest that arguments in favor of policy coordination and fixed rates in the EMS area based on the inefficiencies of non-cooperative policy-making are weak. Since the spillover effects appear to be small (a result also found in a number of large macroeconometric models) gains from policy coordination based on such externalties would be small as well.

3. Fixed exchange rates in the ENS with German leadership of the EMS.

We now consider the case where flexible rates prevail in the rest of the world but the European countries of the model form an fixed exchange rate union (EMS). To define such a fixed rate regime it is necessary to specify the rules according to which the burden of sustaining the fixed parities are distributed among the members of the union. The first case that we will consider is the one of a German leadership of the EMS : Germany sets autonomously its money supply while the other members of the EMS share the burden of sustaining the fixed parities. We will also assume in this section that perfect capital mobility continues to holds in all the regions. Consider first the case of a German fiscal expansion (shown in table 5). The domestic effects of this policy are qualitatively similar to those obtained under flexible exchange rates. German output

8. These results are available upon request from the author.

9. Sensitivity analysis over the main parameters of the model confirms that this result is very robust over a wide range of parameter values. 
goes up and the fiscal multiplier follows the standard hump shaped path. The nominal and real exchange of the Mark relative to the dollar, the yen and the non-EMS currencies appreciates (by around 2.48 ) and the German trade balance deteriorates on impact by 0.69 . Under flexible rates, the Mark would appreciate against all the EMS currencies, as well. Now, however, a fixed rate regime is holding in Europe and the inter-EMS exchange rate must remain fixed. Given the rules of the system (Germany is the leader) all the adjustment is done by the other EMS members that are compelled to reduce their money supplies to avoid a depreciation of their currencies against the Mark. As a result of this monetary contraction, output falls in France, Italy and the rest of the EMS and these country witness a recession. The difference with the flexible rate regime is drastic: under fixed rates, a fiscal expansion in the leader country is negatively transmitted to all the other countries in the union.

Consider now the effects of a fiscal expansion in the other countries of the EMS. Table 6 shows the results for a fiscal expansion in France. The increase in government expenditures leads to an increase in output in France. Under flexible rates, the Franc would tend to appreciate; but, given the necessity to maintain a fixed parity of the Franc in the EMS, the French monetary authorities have to intervene in the foreign exchange market and \or in the domestic monetary market so as to avoid an appreciation. In particular, money supply must be increased so as to compensate the appreciative effects of fiscal policy. This monetary expansion adds to the stimulus of fiscal policy and the increase in output is much larger than under flexible rates: real GNP increases by 1.92 in the first period and after five years is still 0.87 above its steady state value. Notice also that the transmission of this French fiscal-monetary expansion to other EMS countries is very modest.

We consider next, in Table 7, the effects of monetary policy in the leader country, Genmany. Suppose the German authorities decide a 1 percent permanent contraction of the 
German money supply. Under flexible rates, this monetary contraction would lead to an appreciation of the Mark. Now, however, the inter-European exchange rate must remain fixed and the Mark can appreciate only relative to the Dollar, the Yen and the other ROECD currencies. Since Germany is assumed to be the leader of the EMS, the burden of maintaining a fixed inter-European fixed rate in on the monetary authorities of France, Italy and the REMS. Then, monetary policy is contracted in these countries as well and, as a result, all the EMS area is led to a recession: output falls in the first period by 0.7-0.8 in each of the EMS countries. In other terms, the nature of the fixed regime is such that all the countries are compelled to follow the German monetary policy by contracting their money supplies as well 10 .

In a leadership fixed rate regime only the leader country (Gemany) has a full control of its money supply. In the other comtries the money supply is endogenously determined so as to sustain a fixed exchange rate parity. It is known that in the case of a small open economy with fixed rates and perfect capital mobility, an increase in domestic credit will lead to a reduction of foreign reserves of the same amount and no effect on money supply. As table 8 shows, an increase in domestic credit in a follower country (France) leads to a reserve fall equal to the increase in domestic credit and leaves the money supply unchanged. Therefore, the policy is totally ineffective in the initiating country and the intermational transmission is nil as well.

The main conclusion of this section is in a German leadership EMS regime the spillover effects from Germany to the other EMS countries (but not viceversa) are large. However, as suggested by the flexible rates simulations, these spillover effects are not structural (i.e. based on strong interdependence effects); they are rather policy-

10. Notice also that not much happens outside the DMS: the flexible exchange rates of the non-DMS regions insulate them from the effects of monetary policy in the EMS. 
induced in the sense that the constraints imposed by the need to fix the pegged parities on the EMS follower countries' behavior is the source of the large transmission effects.

\section{The EMS as a "cooperative" fixed exchange rate regime.}

The fixed exchange rate regime that we have considered so far has been characterized by the assumption of the monetary leadership of one country (Germany). While many argue that this characterization of the EMS as a 'Mark hegemonic area' or 'Geman leadership regime' is a fair description of the EMS, one should observe that agreements that brought to the formation of the EMS explicitly recognized the risk of a de facto leadership of Germany and, in order to avoid this asymmetry, introduced rules that stressed the need for a symmetry of the adjustment process in front of disturbances that affected the pegged parities. These intervention rules appear to be consistent with a cooperative, rather than hegemonic, exchange rate mechanism.

The purpose of this section is twofold: first, it will be shown how a cooperative exchange rate system such as the one envisioned by the framers of EMS would function and differ from a leadership regime. Secondly, it will be shown that a regine with "cooperative" exchange intervention rules like the EMS cannot prevent the emergence of a de facto leadership of the system if the rules of the system do not include provisions to regulate and restrict domestic sterilization policies by the members of the system.

Consider now a version of the model presented in the sections above where perfect capital mobility holds in all regions, a fixed exchange regime holds in Europe and where the burden of sustaining the pegged parities is symmetrically shared by all the members of the system. It is then necessary to define a set of exchange rate intervention rules so that the inter-EMS parities remain pegged. Given that the total stock of foreign exchange reserves held by the countries of the union is given, a cooperative intervention rule can be defined as one where the weighted sum of the foreign reserves of the members countries is constant. To consider the relative bargaining power of 
larger countries, the weights are chosen so that adjustment burden is greater for smaller countries and smaller for larger countries.

Consider now the effects of this cooperative rule on the effectiveness of monetary policy. We saw above that in a Geman leadership regime, a donestic credit expansion in France would be completely offset by a corresponding fall in French foreign reserves. Here, however, the set of cooperative intervention rules imply that all the countries in the EMS are compelled to intervene to defend the French Franc and the loss of foreign reserve by France is accompanied by an increase in reserves in the other countries of the system. As Table 9 shows, the offset coefficlent for France, following a 18 domestic credit expansion, is still large but less than unity: a 1 \& domestic credit creation leads to a fall of foreign reserves that is equal to $0.73 \%$; as a consequence French money supply increases on impact by 0.13 \&. Correspondingly, the loss of reserves by France leads to an increase in reserves in the other EMS countries: while intervening in the defense of the French currency, the monetary authorities of these countries accumulate the foreign reserves and therefore increase their money supplies.

As indicated above, the offset coefficient is not equal to unity but is still 1arge (73 8); this implies that the increase in the French money supply is modest and the output effect of the monetary expansion very modest: French output rises by 0.11 in the first period and then rapidly corverges back to zero. Nevertheless, the French monetary expansion is now positively transmitted to the other countries of the union because of the monetary expansion in these countries: output grows in Germany, Italy and the REMS at a rate close to the French one. Results (not shown here) qualitatively very similar to those derived for the French domestic expansion can be obtained in the case of domestic credit expansions in Germamy, Italy and the REMS.

The cooperative system described here gives results that are significantly different from the leadership fixed rate case. On one side Germany, then the leader 
country with full control on its money supply, now loses a large portion of its monetary autonomy. On the other side, the remaining countries of the system, then without any control on their money supplies, now regain some modest degree of monetary autonomy.

The difference between the two fixed rate regimes is even more striking with regards to the effects of fiscal policies. Consider, for example, the effects of a German fiscal expansion that is shown in Table 10. As the fiscal expansion starts to increase Geman interest rate and appreciate the Mark, all the countries, including Germany, are forced to intervene to maintain the Mark parity fixed. This means that Germany will acquire foreign reserves and expand its money supply while the other EMS countries lose reserve and contract their money supplies. The result is that German output expands more than it would have in a regime of fixed rates with German leadership while the negative transmission to the output of the other EMS countries in smaller than in the case of German leadership case.

Similarly, when France (or one of the other EMS countries) performs a fiscal expansion, part of the adjustment required to maintain fixed parities is undertaken by all the other countries in the system (see Table 11) instead of France only. Now, France is still expanding its money supply following its fiscal expansion but the degree of monetary expansion is smaller because all the other EMS countries intervene in the exchange market and contract their money supplies. As a result of this simultaneous intervention, the output expansion in France is smaller than the one obtained under the German leadership case while output in the other EMS countries contracts. Similar results are obtained in the case of a fiscal expansion in Italy and the REMS countries.

The results discussed above suggest that a fixed rate system with cooperative exchange intervention rules is very different from a system with a one country leadership: in particular, in this cooperative system, both the monetary and fiscal policies of each one of the members countries, even the relatively smaller ones, are 
transmitted to the other members of the system. These results, however, depend on a crucial assumption: each country of the system allows the reserve flows deriving from the cooperative exchange intervention mechanism to affect its money supply and does not sterilize these effects through open market operation in its domestic credit market. Only if these sterilization policies are not performed the policies of each member countries will be transmitted to the other countries of the system. In reality, assuming that no sterilization policies are performed appears to be unrealistic. A large country like Germany may not feel constrained by the cooperative exchange rate mechanism of the EMS and might perform sterilization policies to undo the effects on its money supply of its intervention in the exchange market whenever its macroeconomic goals are threatened by the policies followed by another EMS country. This hypothesis is reinforced by the evidence that Germany has followed particularly active sterilizations policies in the 1960 's and 1970's 11 .

The important point to stress here it that, once we start to consider sterilization policies, a set of cooperative exchange rate intervention rules is not sufficient to define the actual, as opposed to the formal, symetric or asymmetric nature of a exchange rate union. In particular, any combination of intervention rules can lead to the leadership equilibrium solution if systematic sterilization policies are followed.

The above argument can be exemplified using the simulation model. Suppose that the set of cooperative rules defined at the beginning of this section is followed by the EMS countries. Suppose moreover, that Germany follows a sterilization rule according to which all the reserve flows deriving from its compulsory exchange rate interventions are sterilized for all the monetary shocks external to Germany. Then consider the effects of

11. Studies of sterilization policies include Argy and Kouri (1974), Herring and Marston (1977) and Obstfeld (1978) that considers the German experience in the 60's. For the 1970's see Obstfeld (1982) and Neumarm (1984). For the EMS period, see also Mastropasqua, Micossi and Rinaldi (1988) and Roubini (1988b). 
a 1 domestic credit expansion in France. The results obtained differ substantially from those derived in Table 9 where no sterilization policies were performed. In particular, the results are identical to those in Table 8 (the German leadership regime). In other terms, the results obtained in this case of cooperative rules cum sterilization policies are identical to those obtained in a fixed rate model with German leadership. Moreover, it can be shown the same results could be obtained with any set of exchange rate intervention rules, even one where the weights of the various countries are such that all the intervention is performed by Germany.

These observations lead to conclude that an exchange rate system like the EMS may not be as symetric as the rule of intervention of the system would suggest. In particular, nothing in the EMS agreements limits, regulates or coordinates the sterilization policies that the member countries may follow. It then follows that the actual functioning of the EMS may be totally consistent with an actual leadership of Germany even in the presence of formal joint intervention rules.

5. The role of capital controls in the aMS.

We saw in section 3 that in regime of fixed rates with one country leadership of the system and perfect capital mobility the policy autonomy of follower countries is drastically limited: follower countries are forced to adjust to the fiscal and monetary policies of the leader in directions that may contrary to their policy objectives. Then, the questions to be addressed are: does a regime of limited capital mobility allow a follower country (in a regime of fixed rates) to regain part of the policy autonomy that is lost under perfect capital mobility? Does imperfect capital mobility insulates a countries from the effects of a shock originating in the leader country ? To answer these questions we take the regime of fixed rate with German leadership and add to it the hypothesis of no capital mobility in France and Italy . 
Let us consider first a domestic credit expansion of 28 in France that is shown in Table 12. If foreign exchange reserves did not change, money supply would increase by $1 z$ in this case (reserves are assumed to be half of the monetary base). Table 12 shows that without capital mobility, the offset coefficient is, on impact, smaller than one (the perfect mobility case) but still large: foreign reserves fall by 0.89 \& equivalent to an offset of 45.5 . Given that capital is immobile, the source of the loss of reserves must be the trade balance. The trade balance worsens because imports increase following the growth of output induced by the monetary expansion; moreover, given the fixity of the exchange parity, exports remain substantially unchanged. A trade worsening of 0.098 of GNP then follows in the first year and leads to a loss of reserves equal to 0.89 of these reserves. Monetary autonomy is regained through capital imobility but, as the table shows this autonomy is only limited and temporary. Limited because the impact money multiplier $(0.298)$ is smaller than it was under flexible rate. Temporary, because the string of trade deficits that follow the credit expansion leads to a rapid destruction of foreign reserves that, already by the fifth year, brings the money supply and output close to the level they had before the credit shock. The main result is that lack of capital mobility gives only a partial and temporary autonomy to the country pursuing an expansionary monetary expansion. 12

Consider next the effects of a French fiscal expansion in Table 13. As seen in section 3, a fiscal expansion by a follower country under fixed rates and perfect capital mobility led to a large surge of output because of the induced monetary expansion aimed at maintaining a fixed parity. When we move to no capital mobility case,

12. Traditional static models of fixed rates with no capital mobility (see Marston (1985) for an overview) overstate the degree of monetary autonomy of countries with no capital mobility. In those traditional models, the foreign reserves are not allowed to feed back in the money supply; then, by definition, the reserve offset is equal to zero and a domestic credit expansion has a stronger effect on money supply. Second, these static models do not consider the long-run effects of the string of trade deficits on the foreign reserves and the money supply of the expanding country. 
however, the effects are perverse. The output multiplier is positive only in the first period and, starting in period two, output starts falls so that it is 0.90 below equilibrium by year 5 . What is the source of this effect ? First, a string of trade deficits resulting by real appreciation of the Franc leads to a fall of foreign exchange reserves and money supply (by year five the fall in reserves has led to a fall in money supply of 0.86 8). Second, a fiscal expansion with no capital mobility leads to a very large increase in domestic interest rates $(0.91$ in year one and up to 1.48 in year five). The combined effects of these factors is a reduction in output. One can then observe that, while the lack of capital mobility gives the monetary authorities some temporary monetary autonomy, this has perverse effects for the pursuit of fiscal policy because this policy leads to a recessionary outcome.

We saw above that in a leadership regime with perfect capital mobility the monetary policy of the follower countries is completely subject to the monetary policy of the leader. Can limited capital mobility can restore some of the monetary autonony that is lost by participating to the exchange rate union ? Consider Table 14 where the results of a German monetary contraction are shown. This policy leads to an appreciation of the Mark relative to all the non-EMS currencies. Given that the EMS currencies are tied to the Mark, they all appreciate relative to non-BMS currencies. This leads to a fall in EMS countries exports to the rest of the world and a worsening of their trade balances. However, while Germany finances this trade imbalance through capital imports, France and Italy, that are cutoff from the international financial markets, are forced to run down foreign exchange reserves to finance their trade deficit. The reduction in reserves and money supply therefore leads to a fall in output (by -0.52 .8 on impact as against -0.748 in the case of perfect capital mobility). Then, even if French monetary policy is not tied to the German one, a monetary contraction and output fall occur in France as in the case of fixed rates and perfect capital mobility. Therefore, the decoupling of France 
from German monetary policies is very limited. Actually, the real appreciation of the EMS currencies disappears only after a number of years and, in the meanwile, the continuing French trade deficits lead to increasing reductions in reserves and money supply: by year 5, the French money supply has fallen by $1.00 \%$. It then follows that output contimues to remain below equilibrium throughout the period.

The case of a fiscal expansion in the leader country is another example of how linited capital mobility does not succeed to insulate a follower country from the leader's policies. Under capital mobility, a fiscal expansion in the leader country led to a monetary contraction in the follower countries aimed at maintaining fixed parities. In the case of no capital mobility, given that the inter-EMS exchange rate are fixed, all the EMS currencies are forced to follow the Mark in its nominai and real appreciation relative to the non-FMS currencies. As the Table 15 shows, the nominal (and real) appreciation of the Mark following its fiscal expansion is over $2 \&$ percent and the same appreciation occurs for the other EMS currencies. It then follows that the trade balances of the EMS countries deterlorate and the countries without capital mobility lose foreign exchange reserves. The trade imbalance is larger in the expanding country, Germany, $(-0.65 \&$ in the first year) than in France and Italy $(-0.10$ to -0.11 o $)$ but while Gemany finances this deficit through the capital account without losing foreign reserves, France and Italy lose in the first year more than 1 of their foreign reserves (a contraction of money supply around 0.58 ). This implies a fall in real output of 0.65 in the first year. This output fall is smaller than the one occurring under capital mobility (-1.22 but is still very large. The conclusion is that the lack of capital mobility does not insulate the real variables of the followers from the fiscal policies of the leader of the exchange rate system.

As a summary of this section one can conclude that the lack of capital mobility under fixed rates does a poor job in reaching the two objectives that is usually 
associated with: to regain the policy autonomy (monetary and fiscal) that fixed rates had ellminated for the follower countries in a monetary union and to insulate these countries from the effects of the policies pursued by the leader of the union.

\section{Conclusions.}

This paper is a study of policy interdependence in the EMS area. A number of altemative ways to model the BMS were formulated and their implications for the transmission of macro policies and the potential gains from coordination discussed.

The main results of the paper are the following. First, under flexible exchange rates, the international spillover effects of monetary and fiscal policy in the EMS area would be very small. This suggests that arguments in favor of policy coordination and fixed exchange rates in the EMS area based on the inefficiencies deriving from noncooperative policy making are weak. Since the international spillover effects appear to be small, the potential gains from policy coordination based on these externalties would be small as well. These results are also consistent with the small international multipliers found in many macro-econometric models of the world economy. Second, in a EMS fixed rate system with German leadership the spillover effects are large but they are not structural; they are policy-induced in the sense that the constraints imposed by the need to fix the pegged parities are the source of the large transmission effects. Third, a cooperative EMS regime with joint exchange intervention rules leads to a more symmetric adjustment burden. However, this system can replicate a system with a one country leadership if no rules are imposed on the sterilization policies followed by the member countries. This might explain the paradox of a system like the EMS that is formally cooperative and symmetric but that can be considered as a de facto German leadership system. Fourth, limited capital mobility under fixed rates fails to insure policy autonomy and insulation from extemal disturbances for the countries restricting the capital movements. 


\section{References}

Argy, V. and P. Kouri (1974) "Sterilization Policies and the Volatility in International Reserves", in R.Z. Aliber ed. National Monetary Policies and the Intemational Financial System, University of Chicago Press, Chicago.

Bryant, R.C. and D.W. Henderson, G. Holtham, P. Hooper and S.A. Symansky (1988) (eds.) Empirical Macroeconomics for Interdependent Economies, The Brookings Institution.

Frenkel, J. and A. Razin (1986) "Fiscal Policies and Real Exchange Rates in the world Economy", NBER Working Paper No. 2065, November.

Giavazzi, F. and A. Giovannini (1985) "Asymmetries in Europe, the Dollar and the European Monetary System", in A. Giovannini and R. Dombusch (eds.) Europe and the Dollar, Torino.

(1986) "The EMS and the Dollar", Economic Policy, No.2, 1986.

(1987) "Models of the EMS: Is Europe a Greater Deutsche-Mark Area ?", in R.C. Bryant and R. Portes (eds.) Global Macrceconomics: Pclicy Conflict and Coordination, Macmillan Press.

M.I.T. Press

(1989) Limiting Exchange Rate Flexibility: The European Monetary System,

Giavazzi, F. and M. Pagano (1985) "Capital Controls and the European Monetary System", in Capital Controls and Foreign Exchange Jegislation, Occasional Paper, Euromobiliare, Milano.

Herring, R.J. and R.C. Marston (1977) "National Monetacy Policies and International Financial Markets", North Holland, Amsterdam.

Ishii N., Mckibbin W. and J. Sachs (1985) "The Economic Policy Mix, Policy Cooperation, and Protectionism: Some Aspects of Macroeconomic Interdependence Among the United States, Japan, and Other Countries", Journal of Pollcy Modeling 7 (4).

Lipton, D. and J.D. Sachs (1983) "Accumulation and Growth in a Two-Country Model", Journal of International Economics 15, pp.135-159.

Marston, R. (1985) "Stabilization Policies in Open Economies" in R. Jones and P. Kenen Handbook of International Economics, North Holland.

Mastropasqua, C., S. Micossi and R. Rinaldi (1988) "Interventions, Sterilization and Monetary Policy in the EMS Countries", in F. Glavazzi, S. Micossi and M. Miller (eds.) The European Monetary System, Cambridge University Press, Cambridge.

McKibbin, W. (1986) "The International coordination of Macroeconomic Policies", Unpublished Ph.D. Dissertation, Harvard University.

McKibbin W., N. Roubini and J.D. Sachs (1987) "Correcting Global Imbalances: A Simulation Approach" forthcoming in R. Stern (ed.) U.S. -Canadian Trade and Investment Relations with Japan, Chicago, University of Chicago Press, 1989. 
Neumann, M. (1984) "Intervention in the Mark/Dollar Market: The Authorities' Reaction Function", Journal of International Money and Finance, vol.3.

Obstfeld, M. (1978) "Sterilization and Offsetting Capital Movements: Evidence from West Germany, 1960-1971", urpublished manuscript, M.I.T.

Obstfeld (1982) "Exchange Rates, Inflation, and the Sterilization Problem: Gemany, 1975$1981^{n}$, European Economic Review.

Oudiz G. and J. Sachs (1984), Macroeconomic Policy Coordination among the Industrial Economies," Brookings Papers on Econonic Activity, 1.

(1985) "International Policy Coordination in Dynamic Macroeconomic Models" in W. Buiter and R. Marston (eds.) International Economic Policy Coordination, Cambridge, Cambridge University Press.

Rogoff, K. (1985) "Can International Monetary Policy Coordination be Counterproductive?", Journal of International Economics, 18 .

Roubiri, N. (1988a) "Leadership and Cooperation under Alternative Exchange Rate Regimes: A Simulation Approach", unpublished, Harvard University, April.

Roubini, N. (1988b) "Sterilization Policies, Offsetting Capital Movements and Exchange Rate Intervention Policies in the EMS", mimeo, Yale University.

Sachs, J. and W. McKibbin (1985) "Macroeconomic Policies in the OECD and LDC External Adjustment", NBER Working Paper No.1534, January.

Sachs J.D. and N. Roubini (1987) "Sources of Macroeconomic Imbalances in the World Economy: A Simulation Approach", in Y. Suzuki and M. Okabe (eds.) Towards a World of Economic Stability, University of Tokyo Press, Tokyo, Japan.

APPENDIX. Nodel Parameters, United States

$\begin{array}{llllll}\beta 1=0.332 & \beta 11=-9.000 & \beta 21=0 & \tau 1=0.350 & \tau 2=0.000 & \tau 3=0.000 \\ \beta 2=0.931 & \beta 12=0.202 & \beta 22=1.000 & \sigma 1=1.000 & \sigma 2=1.891 & \sigma 3=0.100 \\ \beta 3=0.000 & \beta 13=0.000 & \beta 23=0.089 & \sigma 4=1.000 & \sigma 5=1.000 & \theta=0.080 \\ \beta 4=0.355 & \beta 14=0.083 & \beta 24=0.000 & \sigma 6=1.000 & \sigma 7=0.60 & \\ \beta 5=0.471 & \beta 15=8.000 & \beta 25=0.250 & \alpha=0.040 & & \\ \beta 6=0.074 & \beta 16=0.933 & \beta 26=0 & & & \\ \beta 7=0.881 & \beta 17=0.022 & \beta 27=0.785 & & \\ \beta 8=0.706 & \beta 18=0.025 & \beta 28=0.050 & & \\ \beta 9=0.263 & \beta 19=1.429 & \beta 29=0.200 & & \\ \beta 10=0.031 & \beta 20=1.000 & \beta 30=0.0 & & \end{array}$


Table 1: Permanent US Monetary Expansion (1\%). Flexible exchange rates in all the regions. Perfect capital mobility.

\begin{tabular}{|c|c|c|c|c|c|c|}
\hline & & 1988 & 1989 & 1990 & 1991 & 1992 \\
\hline \multicolumn{7}{|l|}{ U.S. Economy } \\
\hline output & z & 0.78 & 0.43 & 0.37 & 0.28 & 0.22 \\
\hline Priv Consumption & \&GNP & 0.37 & 0.32 & 0.24 & 0.20 & 0.16 \\
\hline Priv Investment & \&GNP & 0.33 & 0.02 & 0.06 & 0.03 & 0.02 \\
\hline Govt Consumption & \&GNP & 0.00 & 0.00 & 0.00 & 0.00 & 0.00 \\
\hline Exports & \&GNP & 0.05 & 0.05 & 0.04 & 0.03 & 0.02 \\
\hline Imports & \& GNP & 0.06 & 0.03 & 0.03 & 0.02 & 0.02 \\
\hline Imports (quant.) & \& GNP & -0.02 & -0.04 & -0.02 & -0.02 & -0.01 \\
\hline Trade Balance & \& GNP & -0.01 & 0.02 & 0.01 & 0.01 & 0.01 \\
\hline Labour Demand & 8 & 1.04 & 0.46 & 0.38 & 0.25 & 0.27 \\
\hline Inflation & D & 0.33 & 0.13 & 0.12 & 0.08 & 0.06 \\
\hline Int Rate (sh) & D & 0.05 & -0.30 & -0.17 & -0.16 & -0.14 \\
\hline Int Rate (lg) & D & -0.04 & -0.05 & -0.03 & -0.02 & -0.01 \\
\hline \multicolumn{6}{|l|}{ Exchange Rate } & 0.24 \\
\hline s/yen & 8 & 1.35 & 1.50 & 1.30 & 1.22 & 1.12 \\
\hline \$/ger & $\xi$ & 1.34 & 1.48 & 1.29 & 1.20 & 1.11 \\
\hline$\$ /$ fra & $z$ & 1.37 & 1.50 & 1.30 & 1.20 & 1.11 \\
\hline \$/ita & \% & 1.35 & 1.47 & 1.28 & 1.19 & 1.11 \\
\hline \$/ems & $q$ & 1.30 & 1.44 & 1.27 & 1.19 & 1.11 \\
\hline$\$ / o e c$ & q & 1.27 & 1.41 & 1.23 & 1.15 & 1.07 \\
\hline \multicolumn{7}{|c|}{ Real Exchange Rate } \\
\hline$\$ /$ yen & 8 & 1.05 & 1.01 & 0.69 & 0.52 & 0.37 \\
\hline \$/ger & z & 1.04 & 1.00 & 0.65 & 0.47 & 0.32 \\
\hline$\$ /$ fra & z & 1.07 & 1.02 & 0.67 & 0.48 & 0.32 \\
\hline$\$ /$ ita & 8 & 1.04 & 0.98 & 0.65 & 0.46 & 0.32 \\
\hline S/ems & 8 & 1.00 & 0.95 & 0.60 & 0.42 & 0.28 \\
\hline$\$ /$ oec & 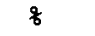 & 0.98 & 0.92 & 0.59 & 0.42 & 0.28 \\
\hline \multicolumn{7}{|l|}{ Japanese Economy } \\
\hline Output & 8 & -0.04 & 0.00 & 0.01 & 0.01 & 0.01 \\
\hline Priv Consumption & IGNP & 0.02 & 0.06 & 0.04 & 0.03 & 0.02 \\
\hline Priv Investment & \&GNP & 0.00 & 0.03 & 0.01 & 0.01 & 0.00 \\
\hline Govt Consumption & \&GNP & 0.00 & 0.00 & 0.00 & 0.00 & 0.00 \\
\hline Exports & \&GNP & -0.03 & -0.05 & -0.02 & -0.01 & -0.00 \\
\hline Imports & \&GNP & -0.00 & 0.00 & 0.00 & 0.00 & 0.00 \\
\hline Imports (quant.) & \&GNP & 0.03 & 0.04 & 0.03 & 0.02 & 0.01 \\
\hline Trade Balance & $\because$ GNP & -0.03 & -0.05 & -0.02 & -0.01 & -0.00 \\
\hline Labour Demand & z & -0.06 & 0.00 & -0.00 & -0.00 & -0.00 \\
\hline Inflation & D & -0.05 & -0.05 & 0.02 & 0.01 & 0.02 \\
\hline Int Rate (sh) & D & -0.09 & -0.11 & -0.08 & -0.06 & -0.05 \\
\hline \multicolumn{7}{|l|}{ German Economy } \\
\hline output & 8 & -0.04 & -0.01 & 0.04 & 0.05 & 0.05 \\
\hline Priv consumption & \&GNP & 0.02 & 0.05 & 0.05 & 0.05 & 0.05 \\
\hline Priv Investment & \&GNP & 0.01 & 0.02 & 0.03 & 0.02 & 0.01 \\
\hline Govt Consumption & \&GNP & 0.00 & 0.00 & 0.00 & 0.00 & 0.00 \\
\hline Exports & \% GNP & -0.03 & -0.03 & -0.01 & 0.01 & 0.01 \\
\hline Imports & \&GNP & -0.00 & 0.01 & 0.02 & 0.02 & 0.01 \\
\hline Imports (quant.) & \&GNP & 0.03 & 0.05 & 0.04 & 0.03 & 0.02 \\
\hline Trade Balance & GNP & -0.03 & -0.05 & -0.02 & -0.01 & 0.00 \\
\hline Labour Demand & के & -0.05 & -0.02 & 0.04 & 0.04 & 0.04 \\
\hline Inflation & $\mathrm{D}$ & -0.05 & -0.05 & -0.01 & 0.00 & 0.01 \\
\hline Int Rate (sh) & $\mathrm{D}$ & -0.08 & -0.11 & -0.08 & -0.07 & -0.06 \\
\hline
\end{tabular}


French Economy

\begin{tabular}{|c|c|c|c|c|c|c|}
\hline Output & $z$ & -0.04 & -0.01 & 0.03 & 0.04 & 0.04 \\
\hline Priv Consumption & \&GNP & 0.02 & 0.04 & 0.05 & 0.05 & 0.04 \\
\hline Priv Investment & \&GNP & 0.01 & 0.02 & 0.02 & 0.01 & 0.01 \\
\hline Govt Consumption & \&GNP & 0.00 & 0.00 & 0.00 & 0.00 & 0.00 \\
\hline Exports & \&GNP & -0.03 & -0.03 & -0.01 & 0.01 & 0.01 \\
\hline Imports & $\% \mathrm{GNP}$ & -0.00 & 0.01 & 0.01 & 0.01 & 0.01 \\
\hline Imports (quant.) & \&GNP & 0.04 & 0.04 & 0.03 & 0.03 & 0.02 \\
\hline Trade Balance & 8GNP & -0.03 & -0.04 & -0.02 & -0.00 & 0.00 \\
\hline Labour Demand & 8 & -0.05 & -0.01 & 0.04 & 0.04 & 0.04 \\
\hline Inflation & D & -0.05 & -0.04 & -0.01 & 0.00 & 0.01 \\
\hline $\begin{array}{l}\text { Int Rate (sh) } \\
\text { Italian Economy }\end{array}$ & D & -0.08 & -0.10 & -0.07 & -0.07 & -0.05 \\
\hline $\begin{array}{l}\text { Italian Economy } \\
\text { output }\end{array}$ & & & & & & \\
\hline $\begin{array}{l}\text { Output } \\
\text { Priv Consumption }\end{array}$ & 8 & -0.03 & -0.01 & 0.03 & 0.04 & 0.05 \\
\hline Priv Consumption & \&GNP & 0.02 & 0.05 & 0.05 & 0.05 & 0.04 \\
\hline Priv Investment & 8 GNP & 0.01 & 0.02 & 0.02 & 0.01 & 0.01 \\
\hline Govt Consumption & \&GNP & 0.00 & 0.00 & 0.00 & 0.00 & 0.00 \\
\hline Exports & \& GNP & -0.03 & -0.04 & -0.01 & 0.01 & 0.02 \\
\hline Imports & \&GNP & 0.00 & 0.01 & 0.01 & 0.01 & 0.01 \\
\hline Imports (quant.) & \& GNP & 0.04 & 0.04 & 0.03 & 0.02 & 0.02 \\
\hline Trade Balance & FGNP & -0.03 & -0.05 & -0.02 & -0.00 & 0.01 \\
\hline Labour Demand & $\frac{8}{8}$ & -0.04 & -0.02 & 0.03 & 0.04 & 0.04 \\
\hline Inflation & D & -0.05 & -0.04 & -0.01 & 0.00 & 0.01 \\
\hline Int Rate (sh) & D & -0.07 & -0.12 & -0.08 & -0.07 & -0.06 \\
\hline Rest of the EMS & & & & & & \\
\hline output & 8 & -0.04 & -0.01 & 0.06 & 0.08 & 0.08 \\
\hline Priv Consumption & \&GNP & 0.03 & 0.06 & 0.07 & 0.07 & 0.07 \\
\hline Priv Investment & \&GNP & 0.01 & 0.03 & 0.03 & 0.02 & 0.01 \\
\hline Govt Consumption & \&GNP & 0.00 & 0.00 & 0.00 & 0.00 & 0.00 \\
\hline Exports & \&GNP & -0.02 & -0.01 & 0.02 & 0.04 & 0.04 \\
\hline Imports & $8 \mathrm{GNP}$ & 0.01 & 0.04 & 0.05 & 0.04 & 0.04 \\
\hline Imports (quant.) & 8 GNP & 0.06 & 0.08 & 0.07 & 0.05 & 0.04 \\
\hline Trade Balance & \& GNP & -0.03 & -0.05 & -0.02 & -0.01 & 0.00 \\
\hline Labour Demand & $\frac{8}{8}$ & -0.06 & -0.01 & 0.07 & 0.08 & 0.08 \\
\hline Inflation & $\mathrm{D}$ & -0.06 & -0.06 & -0.02 & -0.00 & 0.01 \\
\hline Int Rate (sh) & $\mathrm{D}$ & -0.09 & -0.13 & -0.08 & -0.08 & -0.06 \\
\hline Rest of the OECD & Econe & es $(U .1)$ & anada, & $\ldots)$ & & \\
\hline Output & 8 & -0.04 & -0.01 & 0.04 & 0.04 & 0.04 \\
\hline Priv Consumption & \&GNP & 0.02 & 0.05 & 0.05 & 0.05 & 0.04 \\
\hline Priv Investment & \&GNP & 0.01 & 0.03 & 0.03 & 0.02 & 0.01 \\
\hline Govt Consumption & $8 \mathrm{GNP}$ & 0.00 & 0.00 & 0.00 & 0.00 & 0.00 \\
\hline Exports & \&GNP & -0.02 & -0.03 & -0.01 & 0.00 & 0.01 \\
\hline Imports & \&GNP & -0.00 & 0.01 & 0.01 & 0.01 & 0.01 \\
\hline Imports (quant.) & \&GNP & 0.05 & 0.06 & 0.04 & 0.03 & 0.02 \\
\hline Trade Balance & \&GNP & -0.02 & -0.04 & -0.02 & -0.00 & 0.00 \\
\hline Labour Demand & 8 & -0.05 & -0.02 & 0.04 & 0.04 & 0.03 \\
\hline Inflation & D & -0.06 & -0.05 & -0.00 & 0.01 & 0.02 \\
\hline Int Rate (sh) & $\mathrm{D}$ & -0.08 & -0.13 & -0.09 & -0.08 & -0.07 \\
\hline
\end{tabular}

-

Notes:

\& : Percentuage Change from Base Level

\&GNP : Percentuage of GNP

$D$ : Deviation from the Base Level 
Table 2: Permanent German Monetary Expansion (18). Flexible exchange rates in all the regions. Perfect capital mobility.

\begin{tabular}{|c|c|c|c|c|c|c|}
\hline & & 1988 & 1989 & 1990 & 1991 & 1992 \\
\hline U.S. Economy & & & & & & \\
\hline output & 8 & -0.00 & 0.00 & 0.01 & 0.01 & 0.02 \\
\hline Priv Consumption & \&GNP & 0.00 & 0.01 & 0.01 & 0.01 & 0.01 \\
\hline Priv Investment & \&GNP & 0.00 & 0.01 & 0.01 & 0.01 & 0.01 \\
\hline Trade Balance & \&GNP & -0.00 & -0.00 & -0.00 & -0.00 & -0.00 \\
\hline Inflation & D & -0.01 & -0.01 & -0.00 & -0.00 & -0.00 \\
\hline Int Rate (sh) & D & -0.01 & -0.01 & -0.01 & -0.01 & -0.01 \\
\hline $\begin{array}{l}\text { Tobin's Q } \\
\text { Exchange Rate }\end{array}$ & 8 & 0.05 & 0.06 & 0.06 & 0.05 & 0.05 \\
\hline$\$ /$ yen & 8 & 0.01 & 0.01 & 0.01 & 0.01 & 0.01 \\
\hline$\$ /$ ger & 8 & $-1 \cdot 10$ & -1.26 & -1.16 & -1.12 & -1.08 \\
\hline$\$ /$ fra & z & -0.07 & -0.07 & -0.05 & -0.04 & -0.02 \\
\hline \$/ita & z & -0.07 & -0.08 & -0.05 & -0.04 & -0.03 \\
\hline \$/ems & 8 & -0.11 & -0.12 & -0.08 & -0.06 & -0.04 \\
\hline Real Exchange Rat & & & & & & \\
\hline$\$ /$ yen & q & 0.01 & 0.01 & 0.02 & 0.02 & 0.02 \\
\hline \$/ger & 8 & -0.82 & -0.79 & -0.55 & -0.42 & -0.33 \\
\hline$\$ / f r a$ & 8 & -0.07 & -0.09 & -0.07 & -0.06 & -0.04 \\
\hline$\$ /$ ita & 8 & -0.07 & -0.09 & -0.07 & -0.06 & -0.04 \\
\hline$\$ / e m s$ & 8 & -0.10 & -0.16 & -0.13 & -0.11 & -0.08 \\
\hline Japanese Economy & & & & & & \\
\hline output & z & -0.00 & 0.00 & 0.00 & 0.00 & 0.00 \\
\hline Priv Consumption & 8 GNP & 0.00 & 0.01 & 0.01 & 0.01 & 0.01 \\
\hline Priv Investment & $8 \mathrm{GNP}$ & 0.00 & 0.01 & 0.00 & 0.00 & 0.00 \\
\hline Trade Balance & \&GNP & -0.00 & -0.01 & -0.00 & -0.00 & -0.00 \\
\hline Inflation & $\mathrm{D}$ & -0.01 & -0.01 & 0.00 & 0.00 & 0.00 \\
\hline Int Rate (sh) & $\mathrm{D}$ & -0.01 & -0.01 & -0.01 & -0.01 & -0.01 \\
\hline German Ecenomy & & & & & & \\
\hline output & 8 & 0.85 & 0.51 & 0.39 & 0.31 & 0.26 \\
\hline Priv Consumption & \&GNP & 0.33 & 0.24 & 0.18 & 0.15 & 0.13 \\
\hline Priv Investment & \&GNP & 0.31 & -0.01 & 0.03 & 0.02 & 0.02 \\
\hline Trade Balance & \&GNP & 0.02 & 0.11 & 0.07 & 0.05 & 0.04 \\
\hline Inflation & $\mathrm{D}$ & 0.43 & 0.17 & 0.10 & 0.05 & 0.04 \\
\hline Int Rate (sh) & D & 0.14 & -0.10 & -0.06 & -0.05 & -0.05 \\
\hline Erench Economy & & & & & & \\
\hline output & 8 & -0.00 & 0.00 & 0.02 & 0.02 & 0.02 \\
\hline Priv Consumption & \&GNP & 0.01 & 0.03 & 0.03 & 0.03 & 0.03 \\
\hline Priv Investment & $8 \mathrm{GNP}$ & 0.01 & 0.01 & 0.01 & 0.01 & 0.01 \\
\hline Trade Balance & \&GNP & 0.00 & -0.01 & -0.00 & -0.00 & -0.00 \\
\hline Inflation & $\mathrm{D}$ & -0.03 & -0.02 & -0.00 & 0.00 & 0.00 \\
\hline Int Rate (sh) & D & -0.01 & -0.03 & -0.02 & -0.03 & -0.03 \\
\hline Italian Economy & & & & & & \\
\hline output & 8 & -0.00 & 0.01 & 0.03 & 0.03 & 0.02 \\
\hline Priv Consumption & $8 \mathrm{GNP}$ & 0.01 & 0.03 & 0.03 & 0.03 & 0.03 \\
\hline Priv Investment & \&GNP & 0.01 & 0.01 & 0.01 & 0.01 & 0.01 \\
\hline Trade Balance & \&GNP & 0.01 & -0.01 & -0.00 & -0.00 & -0.00 \\
\hline Inflation & D & -0.03 & -0.03 & -0.00 & 0.00 & 0.00 \\
\hline Rest of the EMS $F$ & conom & & & & & \\
\hline output & 8 & 0.00 & 0.02 & 0.05 & 0.05 & 0.04 \\
\hline Priv Consumption & $\$ \mathrm{GNP}$ & 0.03 & 0.05 & 0.05 & 0.05 & 0.04 \\
\hline Priv Investment & \&GNP & 0.01 & 0.02 & 0.02 & 0.01 & 0.01 \\
\hline Trade Balance & \&GNP & 0.03 & -0.01 & -0.00 & 0.00 & 0.00 \\
\hline Inflation & D & -0.07 & -0.03 & 0.00 & 0.01 & 0.01 \\
\hline
\end{tabular}


Table 3: Permanent US Fiscal Expansion (1\% GNP). Flexible exchange rates in all the regions. Perfect capital mobility.

\begin{tabular}{|c|c|c|c|c|c|c|}
\hline & & 1988 & 1989 & 1990 & 1991 & 1992 \\
\hline \multicolumn{7}{|l|}{ U.S. Economy } \\
\hline & $z$ & 0.33 & 0.36 & 0.35 & 0.26 & 0.13 \\
\hline Priv Consumption & \&GNP & -0.06 & 0.01 & -0.01 & -0.07 & -0.17 \\
\hline Priv Investment & qGNP & -0.05 & -0.13 & -0.14 & -0.19 & -0.23 \\
\hline Govt Consumption & qGNP & 1.00 & 1.00 & 1.00 & 1.00 & 1.00 \\
\hline Trade Balance & \&GNP & -0.25 & -0.24 & -0.23 & -0.23 & -0.22 \\
\hline Inflation & D & -0.21 & -0.09 & 0.04 & 0.12 & 0.19 \\
\hline Int Rate (sh) & D & 0.72 & 0.56 & 0.60 & 0.64 & 0.73 \\
\hline Int Rate (1g) & D & 0.21 & 0.15 & 0.11 & 0.08 & 0.04 \\
\hline Tobin's $Q$ & 8 & -3.14 & -2.96 & -3.07 & -3.26 & -3.53 \\
\hline $\begin{array}{l}\text { \$/yen } \\
\text { Sxchange }\end{array}$ & $q$ & -4.57 & -4.43 & -4.31 & -4.26 & -4.21 \\
\hline \$/ger & z & -4.35 & -4.12 & -3.94 & -3.80 & -3.68 \\
\hline \$/fra & q & -4.63 & -4.36 & -4.14 & -3.98 & -3.83 \\
\hline \$/ita & q & -4.46 & -4.18 & -3.97 & -3.81 & -3.66 \\
\hline$\$ /$ ems & $\frac{8}{8}$ & -4.16 & -3.95 & -3.78 & -3.65 & -3.53 \\
\hline \multicolumn{7}{|l|}{ Real Exchange Rate } \\
\hline$\$ /$ yen & q & -4.42 & -3.97 & -3.75 & -3.74 & -3.79 \\
\hline$\$ /$ ger & q & -4.23 & -3.70 & -3.35 & -3.14 & -3.01 \\
\hline$\$ /$ fra & 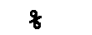 & -4.51 & -3.92 & -3.53 & -3.31 & -3.16 \\
\hline \$/ita & q & -4.30 & -3.71 & -3.33 & -3.10 & -2.97 \\
\hline$\$ / e m s$ & $q$ & -4.01 & -3.45 & -3.07 & -2.86 & -2.74 \\
\hline \multicolumn{7}{|l|}{ Japanese Economy } \\
\hline Output & q & 0.26 & -0.03 & -0.09 & -0.14 & -0.19 \\
\hline Priv Consumption & $8 \mathrm{GNP}$ & -0.20 & -0.30 & -0.37 & -0.40 & -0.44 \\
\hline Priv Investment & \&GNP & -0.11 & -0.26 & -0.22 & -0.23 & -0.23 \\
\hline Trade Balance & $8 \mathrm{GNP}$ & 0.39 & 0.37 & 0.34 & 0.33 & 0.32 \\
\hline Inflation & D & 0.27 & 0.19 & 0.12 & 0.08 & 0.09 \\
\hline Int Rate (sh) & $\mathrm{D}$ & 0.58 & 0.44 & 0.55 & 0.60 & 0.66 \\
\hline \multicolumn{7}{|l|}{ German Economy } \\
\hline output & z & 0.22 & -0.04 & -0.20 & -0.37 & -0.51 \\
\hline Priv Consumption & \&GNP & -0.17 & -0.25 & -0.36 & -0.45 & -0.54 \\
\hline Priv Investment & \&GNP & -0.10 & -0.23 & -0.24 & -0.27 & -0.28 \\
\hline Trade Balance & \&GNP & 0.32 & 0.29 & 0.25 & 0.22 & 0.20 \\
\hline Inflation & D & 0.25 & 0.18 & 0.19 & 0.18 & 0.18 \\
\hline Int Rate (sh) & $\mathrm{D}$ & 0.49 & 0.38 & 0.46 & 0.51 & 0.59 \\
\hline \multicolumn{7}{|l|}{ French Economy } \\
\hline output & q & 0.20 & -0.07 & -0.23 & -0.39 & -0.52 \\
\hline Priv Consumption & \&GNP & -0.18 & -0.27 & -0.36 & -0.45 & -0.54 \\
\hline Priv Investment & rGNP & -0.10 & -0.23 & -0.23 & -0.26 & -0.28 \\
\hline Trade Balance & \&GNP & 0.27 & 0.25 & 0.21 & 0.18 & 0.16 \\
\hline Int Rate (sh) & $\mathrm{D}$ & 0.44 & 0.35 & 0.44 & 0.49 & 0.57 \\
\hline \multicolumn{7}{|l|}{ Italian Economy } \\
\hline Output & z & 0.19 & -0.08 & -0.24 & -0.41 & -0.55 \\
\hline Priv Consumption & \&GNP & -0.19 & -0.28 & -0.37 & -0.45 & -0.53 \\
\hline Priv Investment & \&GNP & -0.13 & -0.24 & -0.24 & -0.27 & -0.28 \\
\hline Trade Balance & \&GNP & 0.31 & 0.27 & 0.23 & 0.19 & 0.17 \\
\hline Int Rate (sh) & D & 0.44 & 0.36 & 0.44 & 0.49 & 0.56 \\
\hline \multicolumn{7}{|c|}{ Rest of the EMS Economies } \\
\hline Output & 8 & 0.24 & -0.11 & -0.30 & -0.49 & -0.64 \\
\hline Priv Consumption & \&GNP & -0.21 & -0.32 & -0.43 & -0.53 & -0.62 \\
\hline Priv Investment & $\begin{array}{l}\text { \&GNP } \\
\text { RGNP }\end{array}$ & $\begin{array}{r}-0.12 \\
0.33\end{array}$ & $\begin{array}{r}-0.27 \\
0.31\end{array}$ & $\begin{array}{r}-0.26 \\
0.26\end{array}$ & $\begin{array}{r}-0.28 \\
0.22\end{array}$ & -0.29 \\
\hline Trade Balance & qेGNP & 0.33 & 0.31 & 0.26 & 0.22 & \\
\hline
\end{tabular}


Table 4: Permanent German Fiscal Expansion (18GNP). Flexible exchange rates in all the regions. Perfect capital mobility.

\begin{tabular}{|c|c|c|c|c|c|c|}
\hline & & 1988 & 1989 & 1990 & 1991 & 1992 \\
\hline \multicolumn{7}{|l|}{ U.S. Economy } \\
\hline output & $q$ & 0.02 & -0.02 & -0.04 & -0.07 & -0.09 \\
\hline Priv Consumption & \&GNP & -0.03 & -0.04 & -0.06 & -0.08 & -0.09 \\
\hline Priv Investment & \&GNP & -0.02 & -0.04 & -0.04 & -0.04 & -0.05 \\
\hline Trade Balance & \&GNP & 0.03 & 0.03 & 0.03 & 0.03 & 0.03 \\
\hline Inflation & $\mathrm{D}$ & 0.05 & 0.03 & 0.03 & 0.03 & 0.03 \\
\hline Int Rate (sh) & D & 0.05 & 0.04 & 0.06 & 0.07 & 0.09 \\
\hline \multicolumn{7}{|l|}{ Exchange Rate } \\
\hline$\$ /$ Yen & 8 & -0.03 & -0.04 & -0.06 & -0.07 & -0.09 \\
\hline$\$ /$ ger & 8 & 2.23 & 2.14 & 2.03 & 1.96 & 1.89 \\
\hline$\$ /$ fra & $\mathbf{z}$ & 0.58 & 0.54 & 0.52 & 0.50 & 0.48 \\
\hline$\$ /$ ita & 8 & 0.57 & 0.53 & 0.52 & 0.50 & 0.48 \\
\hline$\$ /$ ems & 8 & 0.89 & 0.83 & 0.79 & 0.77 & 0.74 \\
\hline \multicolumn{7}{|c|}{ Real Exchange Rate } \\
\hline$\$ /$ yen & q & -0.02 & -0.04 & -0.06 & -0.09 & -0.12 \\
\hline$\$ /$ ger & g & 2.14 & 1.81 & 1.62 & 1.55 & 1.53 \\
\hline$\$ /$ fra & z & 0.57 & 0.52 & 0.50 & 0.48 & 0.47 \\
\hline$\$ /$ ita & 8 & 0.55 & 0.51 & 0.49 & 0.48 & 0.46 \\
\hline$\$ /$ ems & f & 0.84 & 0.75 & 0.69 & 0.66 & 0.64 \\
\hline \multicolumn{7}{|l|}{ Japanese Economy } \\
\hline output & z & 0.02 & -0.01 & -0.02 & -0.02 & -0.03 \\
\hline Priv Consumption & \&GNP & -0.03 & -0.05 & -0.06 & -0.07 & -0.08 \\
\hline Priv Investment & $8 \mathrm{GNP}$ & -0.03 & -0.04 & -0.04 & -0.04 & -0.04 \\
\hline Trade Balance & \&GNP & 0.05 & 0.04 & 0.04 & 0.05 & 0.05 \\
\hline Inflation & $\mathrm{D}$ & 0.05 & 0.03 & 0.02 & 0.02 & 0.02 \\
\hline Int Rate (sh) & D & 0.06 & 0.05 & 0.07 & 0.09 & 0.10 \\
\hline \multicolumn{7}{|l|}{ German Economy } \\
\hline Output & 8 & 0.08 & 0.29 & 0.34 & 0.31 & 0.25 \\
\hline Priv Consumption & \&GNP & 0.12 & 0.20 & 0.21 & 0.17 & 0.11 \\
\hline Priv Investment & \&GNP & 0.02 & 0.05 & 0.02 & -0.01 & -0.04 \\
\hline Govt Consumption & \&GNP & 1.00 & 1.00 & 1.00 & 1.00 & 1.00 \\
\hline Trade Balance & \&GNP & -0.66 & -0.63 & -0.59 & -0.57 & -0.55 \\
\hline Inflation & $\mathrm{D}$ & -0.40 & -0.14 & -0.02 & 0.05 & 0.08 \\
\hline Int Rate (sh) & D & 0.14 & 0.15 & 0.13 & 0.14 & 0.17 \\
\hline \multicolumn{7}{|l|}{ French Economy } \\
\hline output & 8 & 0.04 & -0.01 & -0.02 & -0.05 & -0.07 \\
\hline Priv Consumption & \&GNP & -0.04 & -0.05 & -0.06 & -0.07 & -0.09 \\
\hline Priv Investment & ҰGNP & -0.01 & -0.04 & -0.04 & -0.05 & -0.06 \\
\hline Trade Balance & \&GNP & 0.06 & 0.06 & 0.06 & 0.06 & 0.05 \\
\hline Inflation & D & 0.05 & 0.02 & 0.02 & 0.03 & 0.04 \\
\hline \multicolumn{5}{|l|}{ Italian Economy } & & 0.11 \\
\hline Output & z & 0.04 & -0.01 & -0.03 & -0.05 & -0.08 \\
\hline Priv Consumption & $\because \mathrm{GNP}$ & -0.04 & -0.05 & -0.07 & -0.08 & -0.10 \\
\hline Priv Investment & $8 \mathrm{GNP}$ & -0.02 & -0.05 & -0.04 & -0.05 & -0.06 \\
\hline Trade Balance & \&GNP & 0.05 & 0.06 & 0.05 & 0.05 & 0.05 \\
\hline Inflation & D & 0.06 & 0.02 & 0.02 & 0.03 & 0.04 \\
\hline \multicolumn{7}{|c|}{ Rest of the EMS Economies } \\
\hline output & 8 & 0.06 & 0.04 & 0.04 & 0.02 & -0.00 \\
\hline Priv Consumption & \&GNP & -0.02 & -0.01 & -0.01 & -0.01 & -0.03 \\
\hline Priv Investment & \&GNP & -0.01 & -0.04 & -0.03 & -0.04 & -0.05 \\
\hline Trade Balance & \&GNP & 0.09 & 0.10 & 0.10 & 0.10 & 0.09 \\
\hline Inflation & D & -0.00 & -0.01 & 0.01 & 0.03 & 0.04 \\
\hline
\end{tabular}


Table 5: Permanent German Fiscal Expansion (1\% GNP). Fixed Rate EMS System with German Leadership. Perfect Capital Mobility.

\begin{tabular}{|c|c|c|c|c|c|c|}
\hline & & 1988 & 1989 & 1990 & 1991 & 1992 \\
\hline \multicolumn{7}{|l|}{ U.S. Economy } \\
\hline output & q & 0.03 & -0.02 & -0.07 & -0.09 & -0.12 \\
\hline Trade Balance & \&GNP & 0.03 & 0.04 & 0.03 & 0.03 & 0.03 \\
\hline Inflation & D & 0.07 & 0.05 & 0.04 & 0.03 & 0.03 \\
\hline Int Rate (sh) & $\mathrm{D}$ & 0.06 & 0.07 & 0.08 & 0.11 & 0.12 \\
\hline \multicolumn{7}{|l|}{ Exchange Rate } \\
\hline $\begin{array}{l}\text { \$/yen } \\
\text { \$/ger }\end{array}$ & $q$ & $\begin{array}{r}-0.04 \\
2.40\end{array}$ & $\begin{array}{r}-0.05 \\
2.30\end{array}$ & $\begin{array}{r}-0.06 \\
2.10\end{array}$ & $\begin{array}{r}-0.07 \\
2.00\end{array}$ & $\begin{array}{r}-0.09 \\
1.89\end{array}$ \\
\hline $\begin{array}{l}\text { \$/ger } \\
\text { \$/fra }\end{array}$ & $\begin{array}{l}8 \\
8\end{array}$ & $\begin{array}{l}2.40 \\
2.40\end{array}$ & $\begin{array}{l}2.30 \\
2.30\end{array}$ & $\begin{array}{l}2.10 \\
2.10\end{array}$ & 2.00 & $\begin{array}{l}1.89 \\
1.89\end{array}$ \\
\hline $\begin{array}{l}\text { \$/fra } \\
\text { \$/ita }\end{array}$ & $\begin{array}{l}z \\
z\end{array}$ & $\begin{array}{l}2.40 \\
2.40\end{array}$ & 2.30 & 2.10 & 2.00 & 1.89 \\
\hline \$/ems & q & 2.40 & 2.30 & 2.10 & 2.00 & 1.89 \\
\hline \multicolumn{7}{|c|}{ Real Exchange Rate } \\
\hline$\$ /$ yen & q & -0.01 & -0.03 & -0.07 & -0.11 & -0.14 \\
\hline \$/ger & $q$ & 2.30 & 2.02 & 1.74 & 1.63 & 1.55 \\
\hline \$ fra & $q$ & 1.94 & 1.76 & 1.35 & 1.16 & 0.96 \\
\hline$\$ /$ ita & o & 1.94 & 1.71 & 1.32 & 1.12 & 0.93 \\
\hline \$/ems & f & 1.90 & 1.46 & 1.04 & 0.85 & 0.70 \\
\hline \multicolumn{7}{|l|}{ Japanese Economy } \\
\hline output & z & 0.03 & -0.01 & -0.02 & -0.03 & -0.04 \\
\hline Trade Balance & \&GNP & 0.05 & 0.06 & 0.05 & 0.05 & 0.05 \\
\hline Inflation & $\mathrm{D}$ & 0.07 & 0.05 & 0.02 & 0.02 & 0.01 \\
\hline \multicolumn{7}{|l|}{ German Economy } \\
\hline output & q & 0.08 & 0.28 & 0.28 & 0.27 & 0.21 \\
\hline Priv Consumption & \&GNP & 0.07 & 0.12 & 0.13 & 0.10 & 0.05 \\
\hline Priv Investment & \&GNP & 0.00 & 0.03 & -0.02 & -0.03 & -0.05 \\
\hline Govt Consumption & \%GNP & 1.00 & 1.00 & 1.00 & 1.00 & 1.00 \\
\hline Trade Balance & 8GNP & -0.69 & -0.60 & -0.58 & -0.56 & -0.54 \\
\hline Inflation & D & -0.29 & -0.10 & -0.03 & 0.03 & 0.06 \\
\hline Int Rate (sh) & $\mathrm{D}$ & 0.16 & 0.26 & 0.19 & 0.22 & 0.23 \\
\hline \multicolumn{7}{|l|}{$\begin{array}{l}\text { Int Rate (sn) } \\
\text { French Economy }\end{array}$} \\
\hline output & $z$ & -1.22 & -0.54 & -0.64 & -0.49 & -0.47 \\
\hline Priv Consumption & \&GNP & -0.61 & -0.36 & -0.37 & -0.32 & -0.32 \\
\hline Priv Investment & $8 \mathrm{GNP}$ & -0.49 & 0.04 & -0.15 & -0.07 & -0.10 \\
\hline Trade Balance & \&GNP & 0.04 & -0.06 & 0.01 & 0.00 & 0.02 \\
\hline Inflation & D & -0.49 & -0.03 & -0.13 & -0.03 & -0.03 \\
\hline Int Rate (sh) & $\mathrm{D}$ & 0.16 & 0.26 & 0.19 & 0.22 & 0.23 \\
\hline \multicolumn{7}{|l|}{ Italian Economy } \\
\hline Output & 8 & -1.20 & -0.55 & -0.62 & -0.48 & -0.46 \\
\hline Priv Consumption & \&GNP & -0.60 & -0.36 & -0.36 & -0.32 & -0.31 \\
\hline Priv Investment & \&GNP & -0.46 & 0.04 & -0.14 & -0.07 & -0.10 \\
\hline Trade Balance & \&GNP & 0.04 & -0.06 & 0.01 & 0.01 & 0.03 \\
\hline Inflation & D & -0.49 & -0.06 & -0.13 & -0.04 & -0.02 \\
\hline Int Rate (sh) & $\mathrm{D}$ & 0.16 & 0.26 & 0.19 & 0.22 & 0.23 \\
\hline Money Supply & 8 & -1.60 & -1.09 & -1.28 & -1.23 & -1.26 \\
\hline \multicolumn{7}{|c|}{ Rest of the EMS Economies } \\
\hline output & 8 & -1.21 & -0.38 & -0.30 & -0.17 & -0.15 \\
\hline Priv Consumption & \&GNP & -0.57 & -0.24 & -0.19 & -0.14 & -0.13 \\
\hline Priv Investment & \&GNP & -0.44 & 0.11 & -0.06 & -0.04 & -0.06 \\
\hline Inflation & D & -0.64 & -0.17 & -0.10 & -0.01 & 0.03 \\
\hline Int Rate (sh) & $D$ & 0.16 & 0.26 & 0.19 & 0.22 & 0.23 \\
\hline Money Supply & 8 & -1.59 & -1.13 & -1.21 & -1.16 & -1.14 \\
\hline
\end{tabular}


Table 6: Permanent French Fiscal Expansion (1\% GNP). Fixed Rate EMS System with German Leadership. Perfect Capital mobility.

\begin{tabular}{|c|c|c|c|c|c|c|}
\hline & & 1988 & 1989 & 1990 & 1991 & 1992 \\
\hline \multicolumn{7}{|l|}{ U.S. Economy } \\
\hline Output & 8 & 0.01 & -0.01 & -0.02 & -0.04 & -0.05 \\
\hline Trade Balance & $\&$ GNP & 0.02 & 0.02 & 0.02 & 0.02 & 0.02 \\
\hline Inflation & $\mathrm{D}$ & 0.02 & 0.01 & 0.02 & 0.02 & 0.02 \\
\hline Int Rate (sh) & $\mathrm{D}$ & 0.02 & 0.01 & 0.03 & 0.04 & 0.05 \\
\hline \multicolumn{7}{|l|}{ Exchange Rate } \\
\hline \$/Yen & 8 & -0.03 & -0.04 & -0.05 & -0.05 & -0.07 \\
\hline \$/ger & 8 & 0.38 & 0.34 & 0.37 & 0.37 & 0.38 \\
\hline$\$ /$ fra & 8 & 0.38 & 0.34 & 0.37 & 0.37 & 0.38 \\
\hline \$/ita & 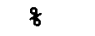 & 0.38 & 0.34 & 0.37 & 0.37 & 0.38 \\
\hline \$/ems & 8 & 0.38 & 0.34 & 0.37 & 0.37 & 0.38 \\
\hline \multicolumn{7}{|c|}{ Real Exchange Rate } \\
\hline \$/yen & 8 & -0.02 & -0.03 & -0.04 & -0.06 & -0.08 \\
\hline \$/ger & 8 & 0.37 & 0.30 & 0.32 & 0.32 & 0.34 \\
\hline s/fra & 8 & 1.09 & 0.91 & 1.13 & 1.25 & 1.45 \\
\hline \$/ita & 8 & 0.44 & 0.37 & 0.40 & 0.40 & 0.43 \\
\hline$\$ / e m s$ & 8 & 0.44 & 0.35 & 0.38 & 0.38 & 0.41 \\
\hline \multicolumn{7}{|l|}{ Japanese Economy } \\
\hline output & q & 0.01 & -0.00 & -0.01 & -0.02 & -0.02 \\
\hline Trade Balance & $\because$ GNP & 0.03 & 0.02 & 0.03 & 0.03 & 0.03 \\
\hline Inflation & D & 0.03 & 0.01 & 0.02 & 0.01 & 0.02 \\
\hline \multicolumn{7}{|l|}{ German Economy } \\
\hline output & $q$ & 0.03 & -0.00 & 0.02 & -0.01 & -0.02 \\
\hline Priv Consumption & \&GNP & -0.01 & 0.00 & -0.00 & -0.01 & -0.03 \\
\hline Priv Investment & $\&$ GNP & -0.00 & -0.02 & -0.01 & -0.03 & -0.03 \\
\hline Trade Balance & $8 \mathrm{GNP}$ & 0.06 & 0.03 & 0.04 & 0.04 & 0.04 \\
\hline Inflation & D & -0.00 & -0.02 & 0.02 & 0.02 & 0.03 \\
\hline Int Rate (sh) & D & 0.07 & -0.02 & 0.03 & 0.02 & 0.05 \\
\hline \multicolumn{7}{|l|}{ French Economy } \\
\hline Output & 8 & 1.92 & 1.07 & 1.25 & 0.99 & 0.87 \\
\hline Govt Consumption & $8 \mathrm{GNP}$ & 1.00 & 1.00 & 1.00 & 1.00 & 1.00 \\
\hline Trade Balance & \&GNP & -0.59 & -0.36 & -0.45 & -0.42 & -0.43 \\
\hline Inflation & D & 0.39 & -0.11 & 0.17 & 0.12 & 0.16 \\
\hline Int Rate (sh) & D & 0.07 & -0.02 & 0.03 & 0.02 & 0.05 \\
\hline Money Supply & 8 & 2.40 & 1.46 & 1.82 & 1.70 & 1.76 \\
\hline \multicolumn{7}{|l|}{ Italian Economy } \\
\hline output & q & 0.07 & 0.01 & 0.04 & 0.01 & -0.01 \\
\hline Priv Consumption & $8 \mathrm{GNP}$ & 0.01 & 0.01 & 0.01 & -0.00 & -0.02 \\
\hline Priv Investment & $\because \mathrm{GNP}$ & 0.01 & -0.03 & -0.01 & -0.03 & -0.03 \\
\hline Trade Balance & \&GNP & 0.06 & 0.04 & 0.05 & 0.05 & 0.05 \\
\hline Inflation & $D$ & 0.01 & -0.02 & 0.02 & 0.03 & 0.04 \\
\hline Int Rate (sh) & D & 0.07 & -0.02 & 0.03 & 0.02 & 0.05 \\
\hline Money Supply & \& & 0.05 & 0.03 & 0.04 & 0.04 & 0.05 \\
\hline \multicolumn{7}{|c|}{ Rest of the EMS Economies } \\
\hline Output & z & 0.15 & 0.04 & 0.10 & 0.06 & 0.04 \\
\hline Priv Consumption & \&GNP & 0.06 & 0.04 & 0.05 & 0.04 & 0.02 \\
\hline Priv Investment & $\because \mathrm{GNP}$ & 0.04 & -0.03 & 0.01 & -0.03 & -0.03 \\
\hline Trade Balance & \&GNP & 0.09 & 0.06 & 0.07 & 0.07 & 0.06 \\
\hline Inflation & D & -0.00 & -0.02 & 0.02 & 0.03 & 0.04 \\
\hline Int Rate (sh) & D & 0.07 & -0.02 & 0.03 & 0.02 & 0.05 \\
\hline Money Supply & 8 & 0.15 & 0.06 & 0.10 & 0.09 & 0.10 \\
\hline
\end{tabular}


Table 7: Permanent German Monetary Contraction (18). Fixed Rate EMS system with Germany Leadership. Perfect Capital Mobility.

\begin{tabular}{|c|c|c|c|c|c|c|}
\hline & & 1988 & 1989 & 1990 & 1991 & 1992 \\
\hline \multicolumn{7}{|l|}{ U.S. Economy } \\
\hline output & 8 & 0.01 & -0.01 & -0.03 & -0.03 & -0.04 \\
\hline Trade Balance & \&GNP & 0.00 & 0.01 & 0.01 & 0.01 & 0.00 \\
\hline Inflation & D & 0.03 & 0.02 & 0.01 & 0.01 & 0.00 \\
\hline Int Rate (sh) & D & 0.02 & 0.03 & 0.03 & 0.04 & 0.04 \\
\hline \multicolumn{7}{|l|}{ Exchange Rate } \\
\hline \$/yen & 8 & -0.01 & -0.01 & -0.00 & -0.01 & -0.00 \\
\hline$\$ /$ ger & 8 & 1.22 & 1.36 & 1.22 & 1.15 & 1.08 \\
\hline$\$ /$ fra & $q$ & 1.22 & 1.36 & 1.22 & 1.15 & 1.08 \\
\hline \$/ita & z & 1.22 & 1.36 & 1.22 & 1.15 & 1.08 \\
\hline$\$ /$ ems & $q$ & 1.22 & 1.36 & 1.22 & 1.15 & 1.08 \\
\hline \multicolumn{7}{|c|}{ Real Exchange Rate } \\
\hline$\$ /$ yen & z & 0.00 & -0.00 & -0.02 & -0.03 & -0.03 \\
\hline$\$ /$ ger & 8 & 0.94 & 0.93 & 0.65 & 0.48 & 0.36 \\
\hline$\$$ /fra & $q$ & 0.98 & 0.99 & 0.71 & 0.54 & 0.40 \\
\hline \$/ita & s & 0.98 & 0.96 & 0.68 & 0.52 & 0.38 \\
\hline$\$ /$ ems & $z$ & 0.92 & 0.81 & 0.48 & 0.31 & 0.19 \\
\hline \multicolumn{7}{|l|}{ Japanese Economy } \\
\hline output & 8 & 0.01 & -0.00 & -0.01 & -0.01 & -0.01 \\
\hline Trade Balance & \&GNP & 0.01 & 0.01 & 0.01 & 0.01 & 0.01 \\
\hline Inflation & D & 0.02 & 0.02 & -0.00 & -0.00 & -0.00 \\
\hline \multicolumn{7}{|l|}{ German Economy } \\
\hline$\overline{\text { output }}$ & z & -0.84 & -0.53 & -0.44 & -0.35 & -0.29 \\
\hline Priv Consumption & \&GNP & -0.37 & -0.31 & -0.24 & -0.20 & -0.17 \\
\hline Priv Investment & \&GNP & -0.32 & -0.01 & -0.05 & -0.03 & -0.03 \\
\hline Trade Balance & \&GNP & -0.04 & -0.09 & -0.06 & -0.05 & -0.04 \\
\hline Inflation & D & -0.35 & -0.13 & -0.11 & -0.07 & -0.05 \\
\hline Int Rate (sh) & D & -0.12 & 0.18 & 0.10 & 0.10 & 0.10 \\
\hline Money supply & 8 & -1.00 & -1.00 & -1.00 & -1.00 & -1.00 \\
\hline \multicolumn{7}{|l|}{ French Economy } \\
\hline Output & z & -0.74 & -0.47 & -0.41 & -0.33 & -0.28 \\
\hline Priv Consumption & $\because$ GNP & -0.33 & -0.29 & -0.24 & -0.20 & -0.17 \\
\hline Priv Investment & \&GNP & -0.29 & -0.02 & -0.06 & -0.03 & -0.03 \\
\hline Trade Balance & \&GNP & -0.03 & -0.06 & -0.03 & -0.03 & -0.02 \\
\hline Inflation & $\mathrm{D}$ & -0.29 & -0.11 & -0.11 & -0.08 & -0.06 \\
\hline Int Rate (sh) & $\mathrm{D}$ & -0.12 & 0.18 & 0.10 & 0.10 & 0.10 \\
\hline \multicolumn{6}{|l|}{ Italian Economy } & -0.93 \\
\hline Output & 8 & -0.73 & -0.47 & -0.40 & -0.32 & -0.26 \\
\hline Priv Consumption & \&GNP & -0.32 & -0.29 & -0.23 & -0.20 & -0.17 \\
\hline Priv Investment & \&GNP & -0.27 & -0.02 & -0.05 & -0.03 & -0.03 \\
\hline Trade Balance & \&GNP & -0.02 & -0.06 & -0.03 & -0.02 & -0.01 \\
\hline Inflation & D & -0.29 & -0.13 & -0.11 & -0.08 & -0.06 \\
\hline Int Rate (sh) & D & -0.12 & 0.18 & 0.10 & 0.10 & 0.10 \\
\hline Money supply & 8 & -0.84 & -0.90 & -0.91 & -0.93 & -0.94 \\
\hline \multicolumn{7}{|c|}{ Rest of the EMS Economies } \\
\hline output & 8 & -0.92 & -0.48 & -0.33 & -0.22 & -0.16 \\
\hline Priv Consumption & \&GNP & -0.40 & -0.28 & -0.20 & -0.15 & -0.12 \\
\hline Priv Investment & \&GNP & -0.32 & 0.04 & -0.01 & -0.01 & -0.01 \\
\hline Trade Balance & ZGNP & 0.01 & -0.08 & -0.04 & -0.02 & -0.01 \\
\hline Inflation & D & -0.41 & -0.19 & -0.11 & -0.06 & -0.04 \\
\hline Money Supply & 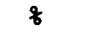 & -1.05 & -1.04 & -1.03 & -1.02 & -1.02 \\
\hline
\end{tabular}


Table 8: Permanent French Domestic Credit Expansion (1\%). Fixed Rate EMS System with German Leadership. Perfect Capital Mobility.

\begin{tabular}{|c|c|c|c|c|c|c|}
\hline & & 1988 & 1989 & 1990 & 1991 & 1992 \\
\hline \multicolumn{7}{|l|}{ French Economy } \\
\hline output & $q$ & 0.00 & 0.00 & 0.00 & 0.00 & -0.00 \\
\hline Money Supply & $z$ & 0.00 & 0.00 & 0.00 & 0.00 & 0.00 \\
\hline Domestic Credit & 8 & 1.00 & 1.00 & 1.00 & 1.00 & 1.00 \\
\hline For. Exc. Reserves & 8 & -1.00 & -1.00 & -1.00 & -1.00 & -1.00 \\
\hline U.S. Output & 8 & 0.00 & 0.00 & 0.00 & 0.00 & 0.00 \\
\hline Japanese output & 8 & 0.00 & 0.00 & 0.00 & 0.00 & 0.00 \\
\hline German output & $z$ & 0.00 & 0.00 & 0.00 & 0.00 & 0.00 \\
\hline Italian Output & 8 & 0.00 & 0.00 & 0.00 & 0.00 & 0.00 \\
\hline REMS output & 8 & 0.00 & 0.00 & 0.00 & 0.00 & 0.00 \\
\hline
\end{tabular}

Table 9. Permanent French Domestic Credit Expansion (1\%). Cooperative Fixed Exchange Rate system in the EMS. Perfect Capital Mobility.

\begin{tabular}{|c|c|c|c|c|c|c|}
\hline & & 1988 & 1989 & 1990 & 1991 & 1992 \\
\hline u.s. Output & z & -0.00 & 0.00 & 0.00 & 0.00 & 0.01 \\
\hline $\begin{array}{l}\text { Japanese Output } \\
\text { Exchange Rate }\end{array}$ & 8 & -0.00 & 0.00 & 0.00 & 0.00 & 0.00 \\
\hline \$/yen & $q$ & 0.00 & 0.00 & 0.00 & 0.00 & 0.00 \\
\hline \$/ger & i & -0.18 & -0.20 & -0.18 & -0.17 & -0.16 \\
\hline$\$$ /fra & q & -0.18 & -0.20 & -0.18 & -0.17 & -0.16 \\
\hline$\$ /$ ita & $q$ & -0.18 & -0.20 & -0.18 & -0.17 & -0.16 \\
\hline$\$ /$ ems & 8 & -0.18 & -0.20 & -0.18 & -0.17 & -0.16 \\
\hline Real Exchange Rat & & & & & & \\
\hline$\$ /$ yen & 8 & -0.00 & 0.00 & 0.00 & 0.00 & 0.00 \\
\hline \$/ger & $q$ & -0.14 & -0.14 & -0.10 & -0.07 & -0.05 \\
\hline$\$ /$ fra & $q$ & -0.15 & -0.15 & -0.11 & -0.08 & -0.06 \\
\hline$\$ / i t a$ & 8 & -0.15 & -0.15 & -0.10 & -0.08 & -0.06 \\
\hline \$/ems & 8 & -0.14 & -0.12 & -0.07 & -0.05 & -0.03 \\
\hline German Economy & & & & & & \\
\hline Output & q & 0.13 & 0.08 & 0.07 & 0.05 & 0.04 \\
\hline Trade Balance & \&GNP & 0.01 & 0.01 & 0.01 & 0.01 & 0.01 \\
\hline Money Supply & 8 & 0.15 & 0.15 & 0.15 & 0.15 & 0.15 \\
\hline Domestic credit & 8 & 0.00 & 0.00 & 0.00 & 0.00 & 0.00 \\
\hline For. Exc.Reserves & q & 0.31 & 0.30 & 0.30 & 0.30 & 0.30 \\
\hline French Economy & & & & & & \\
\hline Output & 8 & 0.11 & 0.07 & 0.06 & 0.05 & 0.04 \\
\hline Trade Balance & \&GNP & 0.00 & 0.01 & 0.01 & 0.00 & 0.00 \\
\hline Money Supply & 8 & 0.13 & 0.13 & 0.14 & 0.14 & 0.14 \\
\hline Domestic Credit & q & 1.00 & 1.00 & 1.00 & 1.00 & 1.00 \\
\hline For. Exc.Reserves & 8 & -0.73 & -0.73 & -0.73 & -0.73 & -0.72 \\
\hline Italian Economy & & & & & & \\
\hline output & q & 0.11 & 0.07 & 0.06 & 0.05 & 0.04 \\
\hline Trade Balance & \&GNP & 0.00 & 0.01 & 0.00 & 0.00 & 0.00 \\
\hline Money Supply & 8 & 0.13 & 0.14 & 0.14 & 0.14 & 0.14 \\
\hline Domestic Credit & $z$ & 0.00 & 0.00 & 0.00 & 0.00 & 0.00 \\
\hline For. Exc.Reserves & ; 8 & 0.26 & 0.27 & 0.27 & 0.28 & 0.28 \\
\hline Rest of the EMS E & conom & & & & & \\
\hline output & 8 & 0.14 & 0.07 & 0.05 & 0.03 & 0.02 \\
\hline Trade Balance & IGNP & -0.00 & 0.01 & 0.01 & 0.00 & 0.00 \\
\hline Money Supply & 8 & 0.16 & 0.16 & 0.15 & 0.15 & 0.15 \\
\hline For. Exc.Reserves & 8 & 0.32 & 0.31 & 0.31 & 0.30 & 0.30 \\
\hline
\end{tabular}


Table 10: Permanent German Fiscal Expansion (1\% GNP). Cooperative Fixed Exchange Rate System in the EMS. Perfect Capital Mobility.

\begin{tabular}{|c|c|c|c|c|c|c|}
\hline & & 1988 & 1989 & 1990 & 1991 & 1992 \\
\hline \multicolumn{7}{|l|}{ U.S. Economy } \\
\hline Output & $z$ & 0.02 & -0.02 & -0.04 & -0.06 & -0.08 \\
\hline Trade Balance & \&GNP & 0.03 & 0.03 & 0.03 & 0.03 & 0.03 \\
\hline Inflation & D & 0.04 & 0.03 & 0.03 & 0.03 & 0.03 \\
\hline \multicolumn{7}{|l|}{ Exchange Rate } \\
\hline \$/yen & 8 & -0.03 & -0.04 & -0.05 & -0.06 & -0.08 \\
\hline \$/ger & 8 & 1.23 & 1.15 & 1.09 & 1.04 & 1.00 \\
\hline \$/fra & 8 & 1.23 & 1.15 & 1.09 & 1.04 & 1.00 \\
\hline$\$ /$ ita & 8 & 1.23 & 1.15 & 1.09 & 1.04 & 1.00 \\
\hline \$/ems & to & 1.23 & 1.15 & 1.09 & 1.04 & 1.00 \\
\hline \multicolumn{7}{|c|}{ Real Exchange Rate } \\
\hline \$/yen & $z$ & -0.01 & -0.03 & -0.05 & -0.08 & -0.11 \\
\hline \$/ger & 8 & 1.41 & 1.20 & 1.17 & 1.17 & 1.21 \\
\hline \$/fra & 8 & 1.00 & 0.88 & 0.73 & 0.64 & 0.56 \\
\hline \$/ita & $q$ & 1.00 & 0.86 & 0.71 & 0.63 & 0.55 \\
\hline \$/ems & 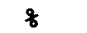 & 1.02 & 0.79 & 0.64 & 0.56 & 0.52 \\
\hline \multicolumn{7}{|l|}{ Japanese Economy } \\
\hline output & 8 & 0.02 & -0.01 & -0.02 & -0.02 & -0.03 \\
\hline Trade Balance & FGNP & 0.04 & 0.04 & 0.04 & 0.05 & 0.05 \\
\hline Inflation & D & 0.05 & 0.03 & 0.02 & 0.02 & 0.02 \\
\hline \multicolumn{7}{|l|}{ German Economy } \\
\hline output & 8 & 0.93 & 0.66 & 0.70 & 0.58 & 0.49 \\
\hline Priv Consumption & \&GNP & 0.45 & 0.35 & 0.35 & 0.28 & 0.21 \\
\hline Priv Investment & \&GNP & 0.32 & -0.02 & 0.06 & -0.00 & -0.01 \\
\hline Govt Consumption & FGNP & 1.00 & 1.00 & 1.00 & 1.00 & 1.00 \\
\hline Trade Balance & FGNP & -0.66 & -0.51 & -0.54 & -0.51 & -0.51 \\
\hline Inflation & D & 0.06 & -0.08 & 0.06 & 0.07 & 0.10 \\
\hline Int Rate (sh) & D & 0.12 & 0.10 & 0.10 & 0.11 & 0.14 \\
\hline Money supply & 8 & 1.11 & 0.75 & 0.85 & 0.81 & 0.82 \\
\hline \multicolumn{7}{|l|}{ French Economy } \\
\hline Output & 8 & -0.46 & -0.21 & -0.24 & -0.20 & -0.21 \\
\hline Priv Consumption & \&GNP & -0.25 & -0.14 & -0.16 & -0.14 & -0.15 \\
\hline Priv Investment & FGNP & -0.20 & 0.00 & -0.07 & -0.05 & -0.07 \\
\hline Trade Balance & FGNP & 0.06 & -0.00 & 0.03 & 0.03 & 0.04 \\
\hline Inflation & D & -0.19 & -0.01 & -0.04 & 0.01 & 0.02 \\
\hline Money supply & 8 & -0.66 & -0.41 & -0.50 & -0.47 & -0.48 \\
\hline For. Exc.Reserves & 8 & -1.32 & -0.82 & -1.00 & -0.94 & -0.96 \\
\hline \multicolumn{7}{|c|}{ Italian Economy } \\
\hline output & 8 & -0.46 & -0.22 & -0.24 & -0.20 & -0.21 \\
\hline Priv Consumption & ZGNP & -0.25 & -0.15 & -0.16 & -0.15 & -0.16 \\
\hline Priv Invesiment & FGNP & -0.19 & -0.00 & -0.07 & -0.05 & -0.06 \\
\hline Trade Balance & zGNP & 0.06 & -0.00 & 0.03 & 0.03 & 0.04 \\
\hline Inflation & D & -0.19 & -0.03 & -0.03 & 0.01 & 0.02 \\
\hline Money Supply & 8 & -0.65 & -0.43 & -0.51 & -0.48 & -0.49 \\
\hline For. Exc.Reserves & t & -1.30 & -0.87 & -1.02 & -0.97 & -0.99 \\
\hline \multicolumn{7}{|c|}{ Rest of the EMS Economies } \\
\hline output & 8 & -0.28 & -0.07 & -0.00 & 0.01 & -0.00 \\
\hline Priv consumption & \&GNP & -0.15 & -0.05 & -0.02 & -0.01 & -0.02 \\
\hline Priv Investment & \&GNP & -0.12 & 0.01 & -0.02 & -0.04 & -0.05 \\
\hline Trade Balance & qGNP & 0.14 & 0.06 & 0.09 & 0.09 & 0.09 \\
\hline Inflation & D & -0.23 & -0.08 & -0.01 & 0.03 & 0.05 \\
\hline Money Supply & $z$ & -0.43 & -0.35 & -0.33 & -0.32 & -0.31 \\
\hline For. Exc. Reserves & 8 & -0.86 & -0.70 & -0.66 & -0.65 & -0.61 \\
\hline
\end{tabular}


Table 11: Permanent French Fiscal Expansion (18 GNP). Cooperative Fixed Exchange Rate System in the EMS. Perfect Capital Mobility.

\begin{tabular}{|c|c|c|c|c|c|c|}
\hline & & 1988 & 1989 & 1990 & 1991 & 1992 \\
\hline \multicolumn{7}{|l|}{ U.S. Economy } \\
\hline Output & 8 & 0.02 & -0.02 & -0.04 & -0.05 & -0.07 \\
\hline Trade Balance & \&GNP & 0.02 & 0.02 & 0.02 & 0.02 & 0.02 \\
\hline & D & 0.04 & 0.03 & 0.03 & 0.02 & 0.02 \\
\hline Exchange Rate & z & -0.04 & -0.04 & -0.05 & -0.06 & -0.07 \\
\hline$\$ /$ ger & 8 & 1.16 & 1.08 & 1.04 & 1.01 & 0.98 \\
\hline \$/fra & 8 & 1.16 & 1.08 & 1.04 & 1.01 & 0.98 \\
\hline \$/ita & 8 & 1.16 & 1.08 & 1.04 & 1.01 & 0.98 \\
\hline$\$ /$ ems & $z$ & 1.16 & 1.08 & 1.04 & 1.01 & 0.98 \\
\hline \multicolumn{7}{|c|}{ Real Exchange Rate } \\
\hline \$/yen & o & -0.02 & -0.03 & -0.05 & -0.08 & -0.10 \\
\hline \$/ger & 8 & 0.96 & 0.84 & 0.70 & 0.63 & 0.58 \\
\hline$\$ /$ fra & 8 & 1.71 & 1.48 & 1.55 & 1.60 & 1.71 \\
\hline$\$ /$ ita & $z$ & 1.06 & 0.93 & 0.80 & 0.74 & 0.68 \\
\hline \$/ems & 8 & 1.03 & 0.79 & 0.65 & 0.58 & 0.54 \\
\hline \multicolumn{7}{|l|}{ Japanese Economy } \\
\hline Output & 8 & 0.02 & -0.01 & -0.01 & -0.02 & -0.03 \\
\hline Trade Balance & 8 GNP & 0.03 & 0.03 & 0.04 & 0.04 & 0.04 \\
\hline Inflation & D & 0.04 & 0.02 & 0.02 & 0.01 & 0.01 \\
\hline \multicolumn{7}{|l|}{ German Economy } \\
\hline output & 8 & -0.54 & -0.24 & -0.27 & -0.22 & -0.22 \\
\hline Priv Consumption & \&GNP & -0.27 & -0.14 & -0.15 & -0.13 & -0.14 \\
\hline Priv Investment & $8 \mathrm{GNP}$ & -0.22 & 0.02 & -0.07 & -0.04 & -0.06 \\
\hline Trade Balance & $\because \mathrm{GNP}$ & 0.04 & -0.04 & 0.01 & 0.00 & 0.01 \\
\hline Inflation & $\mathrm{D}$ & -0.24 & -0.02 & -0.05 & -0.00 & 0.01 \\
\hline Money Supply & 8 & -0.76 & -0.46 & -0.57 & -0.53 & -0.55 \\
\hline For. Exc.Reserves & รै & -1.52 & -0.93 & -1.14 & -1.07 & -1.10 \\
\hline \multicolumn{7}{|l|}{ French Economy } \\
\hline output & 8 & 1.41 & 0.87 & 0.98 & 0.79 & 0.68 \\
\hline Priv Consumption & \&GNP & 0.69 & 0.49 & 0.52 & 0.42 & 0.35 \\
\hline Priv Investment & \&GNP & 0.51 & -0.05 & 0.11 & 0.01 & 0.01 \\
\hline Govt Consumption & 8GNP & 1.00 & 1.00 & 1.00 & 1.00 & 1.00 \\
\hline Trade Balance & \&GNP & -0.60 & -0.41 & -0.47 & -0.44 & -0.44 \\
\hline Inflation & $\mathrm{D}$ & 0.19 & -0.10 & 0.10 & 0.09 & 0.13 \\
\hline Int Rate (sh) & D & 0.11 & 0.07 & 0.08 & 0.09 & 0.11 \\
\hline Money Supply & 8 & 1.72 & 1.07 & 1.30 & 1.22 & 1.26 \\
\hline $\begin{array}{l}\text { For Exc. Reserves } \\
\text { Italian Economy }\end{array}$ & 8 & 3.44 & 2.14 & 2.61 & 2.44 & 2.51 \\
\hline output & 8 & -0.43 & -0.20 & -0.23 & -0.18 & -0.19 \\
\hline Priv Consumption & \&GNP & -0.23 & -0.12 & -0.13 & -0.12 & -0.13 \\
\hline Priv Investment & 8GNP & -0.17 & 0.01 & -0.06 & -0.04 & -0.05 \\
\hline Trade Balance & ₹GNP & 0.05 & -0.00 & 0.03 & 0.03 & 0.04 \\
\hline Inflation & D & -0.19 & -0.03 & -0.04 & -0.00 & 0.01 \\
\hline Money Supply & 8 & -0.61 & -0.38 & -0.48 & -0.45 & -0.46 \\
\hline For. Exc.Reserves & 8 & -1.22 & -0.76 & -0.95 & -0.89 & -0.93 \\
\hline \multicolumn{7}{|c|}{ Rest of the EMS Economies } \\
\hline output & $z$ & -0.47 & -0.14 & -0.11 & -0.06 & -0.06 \\
\hline Priv Consumption & \&GNP & -0.23 & -0.08 & -0.07 & -0.05 & -0.05 \\
\hline Priv Investment & \&GNP & -0.18 & 0.04 & -0.03 & -0.03 & -0.04 \\
\hline Trade Balance & \&GNP & 0.10 & 0.00 & 0.05 & 0.05 & 0.06 \\
\hline Money Supply & 8 & -0.65 & -0.43 & -0.49 & -0.46 & -0.46 \\
\hline For. Exc.Reserves & $z$ & -1.30 & -0.85 & -0.97 & -0.92 & -0.92 \\
\hline
\end{tabular}


Table 12: Permanent French Domestic Credit Expansion (2\%). Fixed Rate EMS with Germany Leadership. No Capital Mobility in France and Italy.

\begin{tabular}{|c|c|c|c|c|c|c|}
\hline & & 1988 & 1989 & 1990 & 1991 & 1992 \\
\hline $\begin{array}{l}\text { U.S Output } \\
\text { Exchange Rate }\end{array}$ & 8 & 0.00 & -0.00 & -0.00 & -0.00 & -0.00 \\
\hline$\$ /$ ger & $\%$ & 0.03 & 0.01 & 0.01 & 0.00 & -0.00 \\
\hline$\$ /$ fra & \% & 0.03 & 0.01 & 0.01 & 0.00 & -0.00 \\
\hline \$/ita & \% & 0.03 & 0.01 & 0.01 & 0.00 & -0.00 \\
\hline$\$ / e m s$ & 8 & 0.03 & 0.01 & 0.01 & 0.00 & -0.00 \\
\hline $\begin{array}{l}\text { Japanese Output } \\
\text { German Economy }\end{array}$ & 8 & 0.00 & -0.00 & -0.00 & -0.00 & -0.00 \\
\hline Output & 8 & 0.01 & 0.00 & 0.00 & 0.00 & 0.00 \\
\hline $\begin{array}{l}\text { Trade Balance } \\
\text { French Economy }\end{array}$ & \&GNP & 0.01 & 0.01 & 0.00 & 0.00 & 0.00 \\
\hline Output & 8 & 0.29 & 0.13 & 0.10 & 0.08 & 0.06 \\
\hline Trade Balance & \% GNP & -0.09 & -0.04 & -0.02 & -0.01 & -0.00 \\
\hline Inflation & D & 0.06 & -0.04 & -0.02 & -0.02 & -0.01 \\
\hline Money supply & 8 & 0.56 & 0.35 & 0.21 & 0.12 & 0.07 \\
\hline Domestic Credit & 8 & 2.00 & 2.00 & 2.00 & 2.00 & 2.00 \\
\hline $\begin{array}{l}\text { For, Exc. Reserves } \\
\text { Italian Economy }\end{array}$ & 8 & -0.89 & -1.31 & -1.59 & -1.76 & -1.86 \\
\hline output & 8 & 0.03 & 0.02 & 0.02 & 0.01 & 0.01 \\
\hline $\begin{array}{l}\text { Trade Balance } \\
\text { Rest of the EMS E }\end{array}$ & $\begin{array}{l}\text { \&GNP } \\
\text { conon }\end{array}$ & 0.01 & 0.00 & -0.00 & -0.00 & -0.00 \\
\hline Output & 8 & 0.03 & 0.00 & 0.00 & -0.00 & -0.00 \\
\hline Trade Balance & क्षGNP & 0.02 & 0.01 & 0.01 & 0.00 & 0.00 \\
\hline
\end{tabular}

Table 13: Permanent French Fiscal Expansion (1\% GNP). Fixed Exchange Rate in the EMS. Germany leader. No Capital Mobility in France and Italy.

\begin{tabular}{|c|c|c|c|c|c|c|}
\hline & & 988 & 1989 & 1990 & 1991 & 1992 \\
\hline $\begin{array}{l}\text { U.S. Output } \\
\text { Exchange Rate }\end{array}$ & 8 & -0.00 & -0.00 & -0.00 & -0.01 & -0.01 \\
\hline \$/yen & 8 & -0.02 & -0.03 & -0.03 & -0.04 & -0.04 \\
\hline \$/ger & $q$ & 0.07 & 0.07 & 0.08 & 0.09 & 0.10 \\
\hline$\$$ /fra & 8 & 0.07 & 0.07 & 0.08 & 0.09 & 0.10 \\
\hline \$/ita & 8 & 0.07 & 0.07 & 0.08 & 0.09 & 0.10 \\
\hline \$/ems & 8 & 0.07 & 0.07 & 0.08 & 0.09 & 0.10 \\
\hline $\begin{array}{l}\text { Japanese Output } \\
\text { German Economy }\end{array}$ & 8 & 0.00 & -0.00 & -0.00 & -0.00 & -0.01 \\
\hline $\begin{array}{l}\text { Output } \\
\text { Trade Balance } \\
\text { French Economy }\end{array}$ & $\stackrel{8}{8}$ & $\begin{array}{r}-0.00 \\
0.00\end{array}$ & $\begin{array}{l}-0.00 \\
-0.00\end{array}$ & $\begin{array}{l}-0.01 \\
-0.00\end{array}$ & $\begin{array}{l}-0.02 \\
-0.01\end{array}$ & $\begin{array}{l}-0.03 \\
-0.01\end{array}$ \\
\hline Output & 8 & 0.19 & -0.08 & -0.33 & -0.62 & -0.90 \\
\hline Trade Balance & \&GNP & -0.07 & -0.03 & -0.03 & -0.02 & -0.02 \\
\hline Inflation & D & 0.04 & 0.10 & 0.18 & 0.21 & 0.23 \\
\hline Int Rate (sh) & D & 0.91 & 0.92 & 1.11 & 1.28 & 1.48 \\
\hline Money Supply & 8 & -0.30 & -0.46 & -0.60 & -0.73 & -0.86 \\
\hline $\begin{array}{l}\text { For. Exc. Reserves } \\
\text { Italian Economy }\end{array}$ & 8 & -0.61 & -0.93 & -1.20 & -1.46 & -1.71 \\
\hline $\begin{array}{l}\text { Output } \\
\text { Trade Balance } \\
\text { Rest of the EMS }\end{array}$ & $\begin{array}{l}\stackrel{8}{z} \\
\text { ENAP } \\
\text { Eonomies }\end{array}$ & $\begin{array}{l}0.00 \\
0.00\end{array}$ & $\begin{array}{l}-0.01 \\
-0.00\end{array}$ & $\begin{array}{l}-0.02 \\
-0.00\end{array}$ & $\begin{array}{l}-0.04 \\
-0.00\end{array}$ & $\begin{array}{l}-0.06 \\
-0.00\end{array}$ \\
\hline $\begin{array}{l}\text { Output } \\
\text { Trade Balance }\end{array}$ & \%GNP & $\begin{array}{l}0.01 \\
0.01\end{array}$ & $\begin{array}{l}0.00 \\
0.00\end{array}$ & $\begin{array}{l}-0.00 \\
-0.01\end{array}$ & $\begin{array}{l}-0.02 \\
-0.01\end{array}$ & $\begin{array}{l}-0.04 \\
-0.01\end{array}$ \\
\hline
\end{tabular}


Table 14: Permanent German Monetary Expansion (1\%). Fixed Rate EMS with German Leadership. No Capital Mobility in France and Italy.

\begin{tabular}{|c|c|c|c|c|c|c|}
\hline & & 1988 & 1989 & 1990 & 1991 & 1992 \\
\hline \multicolumn{7}{|l|}{ U.S. Economy } \\
\hline output & z & 0.01 & -0.01 & -0.03 & -0.03 & -0.03 \\
\hline Trade Balance & \& GNP & 0.01 & 0.01 & 0.01 & 0.00 & 0.00 \\
\hline & \multicolumn{3}{|c|}{ Exchange Rate } & & & 0.04 \\
\hline s/yen & q & -0.00 & -0.00 & -0.00 & -0.00 & 0.00 \\
\hline \$/ger & 8 & 1.24 & 1.36 & 1.21 & 1.14 & 1.07 \\
\hline$\$ /$ fra & q & 1.24 & 1.36 & 1.21 & 1.14 & 1.07 \\
\hline$\$ / i t a$ & $z$ & 1.24 & 1.36 & 1.21 & 1.14 & 1.07 \\
\hline \$/ems & q & 1.24 & 1.36 & 1.21 & 1.14 & 1.07 \\
\hline \multicolumn{7}{|l|}{ Real Exchange Rate } \\
\hline$\$ /$ yen & z & 0.01 & 0.00 & -0.01 & -0.02 & -0.02 \\
\hline \$/ger & $q$ & 0.97 & 0.93 & 0.64 & 0.47 & 0.34 \\
\hline \$/fra & $z$ & 1.05 & 0.98 & 0.67 & 0.48 & 0.34 \\
\hline \$/ita & $q$ & 1.04 & 0.95 & 0.65 & 0.47 & 0.33 \\
\hline Japanese $\begin{array}{c}\$ / \text { ems } \\
\text { Economy }\end{array}$ & $q$ & 0.95 & 0.81 & 0.47 & 0.30 & 0.18 \\
\hline output & f & 0.01 & -0.00 & -0.01 & -0.01 & -0.01 \\
\hline $\begin{array}{l}\text { Trade Balance } \\
\text { German Economi }\end{array}$ & $\because \mathrm{GNP}$ & 0.01 & 0.01 & 0.01 & 0.01 & 0.01 \\
\hline Output & $q$ & -0.82 & -0.53 & -0.44 & -0.35 & -0.28 \\
\hline Priv Consumption & \&GNP & -0.37 & -0.31 & -0.24 & -0.20 & -0.17 \\
\hline Priv Investment & \&GNP & -0.32 & -0.02 & -0.05 & -0.03 & -0.03 \\
\hline Trade Balance & \&GNP & -0.02 & -0.09 & -0.06 & -0.05 & -0.04 \\
\hline Inflation & $\mathrm{D}$ & -0.34 & -0.13 & -0.11 & -0.07 & -0.05 \\
\hline Int Rate (sh) & D & -0.09 & 0.18 & 0.11 & 0.10 & 0.09 \\
\hline Money Supply & $q$ & -1.00 & -1.00 & -1.00 & -1.00 & -1.00 \\
\hline \multicolumn{7}{|l|}{ French Economy } \\
\hline output & $q$ & -0.52 & -0.44 & -0.40 & -0.33 & -0.28 \\
\hline Priv Consumption & $\because \mathrm{GNP}$ & -0.15 & -0.22 & -0.23 & -0.22 & -0.19 \\
\hline Priv Investment & \%GNP & -0.19 & -0.06 & -0.06 & -0.05 & -0.04 \\
\hline Trade Balance & \&GNP & -0.08 & -0.06 & -0.03 & -0.01 & -0.00 \\
\hline Inflation & $\mathrm{D}$ & -0.25 & -0.16 & -0.13 & -0.09 & -0.07 \\
\hline Int Rate (sh) & $\mathrm{D}$ & -0.43 & -0.04 & 0.04 & 0.10 & 0.12 \\
\hline Money Supply & $q$ & -0.41 & -0.73 & -0.89 & -0.97 & -1.01 \\
\hline $\begin{array}{l}\text { For. Exc. Reserves } \\
\text { Italian Economy }\end{array}$ & $q$ & -0.82 & -1.45 & -1.78 & -1.94 & -2.01 \\
\hline output & $q$ & -0.51 & -0.42 & -0.36 & -0.30 & -0.24 \\
\hline Priv Consumption & \&GNP & -0.14 & -0.20 & -0.20 & -0.19 & -0.16 \\
\hline Priv Investment & fGNP & -0.16 & -0.04 & -0.04 & -0.03 & -0.02 \\
\hline Trade Balance & $8 \mathrm{GNP}$ & -0.09 & -0.07 & -0.04 & -0.02 & -0.01 \\
\hline Inflation & D & -0.25 & -0.17 & -0.13 & -0.09 & -0.07 \\
\hline Int Rate (sh) & D & -0.40 & -0.05 & 0.04 & 0.08 & 0.09 \\
\hline Money Supply & $q$ & -0.40 & -0.71 & -0.86 & -0.93 & -0.95 \\
\hline For. Exc.Reserves & \% & -0.80 & -1.42 & -1.72 & -1.86 & -1.91 \\
\hline \multicolumn{7}{|c|}{ Rest of the EMS Economies } \\
\hline output & $q$ & -0.88 & -0.49 & -0.33 & -0.23 & -0.16 \\
\hline Priv Consumption & fGNP & -0.39 & -0.28 & -0.20 & -0.15 & -0.12 \\
\hline Priv Investment & \&GNP & -0.31 & 0.03 & -0.01 & -0.01 & -0.01 \\
\hline Trade Balance & FGNP & 0.03 & -0.08 & -0.04 & -0.02 & -0.01 \\
\hline Inflation & $\mathrm{D}$ & -0.40 & -0.19 & -0.11 & -0.07 & -0.04 \\
\hline Money Supply & 8 & -1.03 & -1.04 & -1.03 & -1.03 & -1.02 \\
\hline For. Exc.Reserves & 8 & -2.06 & -2.08 & -2.05 & -2.05 & -2.04 \\
\hline
\end{tabular}


Table 15: Permanent German Fiscal Expansion (1\% GNP). Fixed Rate EMS with German Leadership. No Capital Mobility in France and Italy.

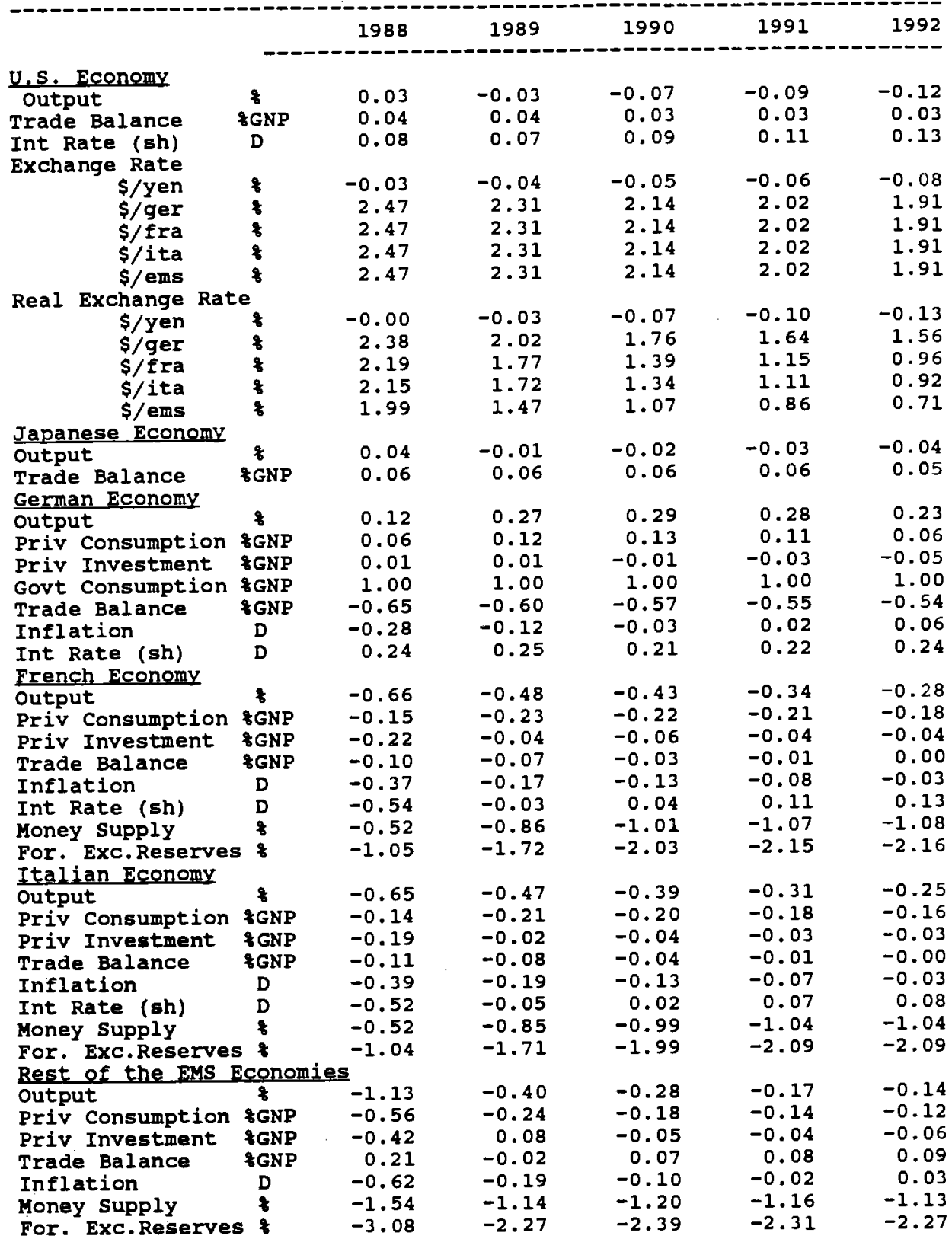

